\title{
Impact of postharvest preservation methods on nutritional value and bioactive properties of mushrooms
}

\author{
Sara Marçal ${ }^{\mathrm{a}, 1}$, Ana Sofia Sousa ${ }^{\mathrm{a}, 1}$, Oludemi Taofiq ${ }^{\mathrm{b}}$, Filipa Antunes ${ }^{\mathrm{a}}$, Alcina M.M.B. Morais ${ }^{\mathrm{a}}$, \\ Ana Cristina Freitas ${ }^{a}$, Lillian Barros ${ }^{b}$, Isabel C.F.R. Ferreira ${ }^{b}$, Manuela Pintado ${ }^{a, *}$

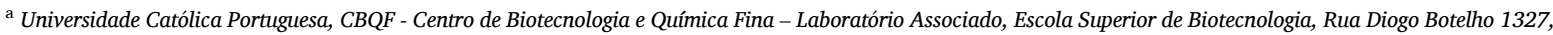 \\ 4169-005, Porto, Portugal \\ ${ }^{\mathrm{b}}$ Centro de Investigação de Montanha (CIMO), Instituto Politécnico de Bragança, Campus de Santa Apolónia, 5300-253, Bragança, Portugal
}

\section{A R T I C L E I N F O}

\section{Keywords:}

Edible mushrooms

Postharvest preservation methods

Nutritional composition

Bioactive properties

\begin{abstract}
A B S T R A C T
Background: Mushrooms are a good source of protein, dietary fibre, vitamins, minerals and phenolic compounds. However, mushrooms are a very perishable food and the implementation of preservation methods is essential to extend their shelf-life. The preservation methods for mushrooms can be classified into three categories: thermal (drying/freezing), chemical (edible coatings, films and washing solutions) and physical (packing, irradiation, pulsed electric field and ultrasound) processes. These processes can change the nutritional value and bioactive properties of this commodity.

Scope and approach: The goal of this review is to critically update and discuss the existing information about the effect of postharvest preservation methods on the nutritional value and bioactive properties of edible mushrooms.

Key findings and conclusions: Drying, especially when high temperatures are applied, can cause the degradation of polysaccharides, proteins and flavour compounds. Freezing is one of the best methods to extend mushrooms' shelf life but cause the loss of vitamins. Edible coatings and films improve the total sugar, ascorbic acid and bioactive compounds preservation during the storage period. Washing solutions decrease amino acids content. Gamma and electron-beam irradiation decrease the unsaturated fatty acid content, whereas UV-B irradiation significantly increases the vitamin D content. However, there is still limited information about the impact of chemical processes, packaging, pulsed electric field and ultrasound on the nutritional composition and bioactive properties of mushrooms, opening research opportunities for future. This review presents technological and economic alternatives that may support the mushroom processing industries to obtain value-added edible mushrooms and related products.
\end{abstract}

\section{Introduction}

Mushrooms are macro-fungi with distinctive fruiting bodies, which are large enough to be seen with the naked eye and to be picked by hand (Chang \& Miles, 1992). According to what mushrooms represent in humans' diet and health, they can be grouped into four categories: edible, medicinal, poisonous and other mushrooms, whose properties are not yet well defined (Cheung, 2010). Some edible mushrooms also have medicinal properties and, therefore, simultaneously belong to the edible and medicinal groups (Guillamón et al., 2010).

Due to their organoleptic, nutritional and medicinal properties, fresh and preserved mushrooms are very appreciated by humans since ancient times (Wani, Bodha, \& Wani, 2010). In the last years, the consumer demand for mushrooms, as well as their production, increased significantly. In 18 years of the new century (2000 up to 2018) the worldwide mushroom production increased from 4,19 to 8,99 million tons/year (FAOSTAT, 2018). Nowadays, more than 20 mushrooms species are commercially cultivated (Kalač, 2013; Rathore, Prasad, \& Sharma, 2017). The most cultivated species are Agaricus bisporus (button mushroom, white or brown, or portobello, representing about $40 \%$ of worldwide production), Lentinula edodes (shiitake, representing about $25 \%$ of worldwide production), Pleurotus spp. (mostly P. ostreatus, oyster

\footnotetext{
* Corresponding author.

E-mail address: mpintado@porto.ucp.pt (M. Pintado).

1 These authors contributed equally to this work.
} 
mushroom, shirataki) and Flammulina velutipes (golden needle mushroom, enokitake) (Duan, Xing, Shao, \& Zhao, 2010; Jiang, Luo, Chen, Shen, \& Ying, 2010). Aside from the cultivated ones, about 200 wild mushrooms species, collected in various parts of the world, are also commercialized (Kalač, 2013). However, there are more than 14000 known species in nature, of which 3000 are edible (El Sheikha \& Hu, 2018). It is expected that the total mushroom production, the number of commercialized species and the importance of mushrooms on the human diet will keep increasing in the following years (Cheung, 2010; El Sheikha \& Hu, 2018). Besides its organoleptic, nutritional and medicinal value, mushrooms are considered a sustainable food product: they increase the soil fertility and contribute to the removal of soil pollutants; the subtracts where they are cultivated can be made of agro-industrial solid organic wastes, and they are a sustainable source of protein. Compared with meat and other animal protein sources, mushrooms need less area and time to produce the same amount of protein (El Sheikha \& Hu, 2018; Wani et al., 2010).

However, the commercialization of fresh mushrooms has a major challenge: they are a very perishable food product and tend to lose quality immediately after being harvested. For example, $A$. bisporus shelf life is 1-3 days, at room temperature, and 8 days, under refrigerated conditions (Zhang, Pu, \& Sun, 2018). Mushrooms have some characteristics that promote their fast degradation, namely, high moisture content, neutral $\mathrm{pH}$, high respiration rate, high level of enzymatic activity, presence of microflora and absence of protective cuticle layer on the skin (Fernandes, Antonio, Oliveira, Martins, \& Ferreira, 2012b; Zhang et al., 2018). The mushrooms quality degradation results in moisture, flavour and nutrients losses, discolouration, texture changes, cap opening, and stipe elongation (Fernandes, Antonio, Oliveira, et al., 2012; Zhang et al., 2018). In its turn, the moisture loss causes changes in texture and weight mushroom decrease and, consequently, reduces their economic value. According to Zhang et al. (2018), when moisture loss is higher than $5 \%$ of mushrooms' fresh weight, they present no commercial value. On the other hand, the appearance of mushrooms is one of the qualitative factors that most influences consumers' purchase behaviour (Nasiri, Barzegar, Sahari, \& Niakousari, 2018). During the storage period, mushrooms tend to acquire brown spots due to conversion of phenolic compounds into quinones, which, in its turn, are converted into melanin (brown pigment). The enzymes involved in these reactions are polyphenol oxidase and, to a lesser extent, phenol peroxidase. Usually, the browning process occurs due to a disruption of mushrooms cellular membrane integrity that enables the contact between phenolic compounds and enzymes. The disruption of membrane integrity can be caused by rough handling, low relative humidity, ageing and presence of pathogenic microorganisms. Pseudomonas tolaasii is the main bacterial pathogen of mushrooms. Pathogenic form of $P$. tolaasii produces extracellular toxins, named tolaasins, with capacity to disrupt mushroom membrane. Besides P. tolaasii, other species of microorganisms have been associated with mushrooms' discolouration, for instance, Pseudomonas costantinii and Pseudomonas reactants (Lin \& Sun, 2019).

The development and implementation of preservation methods are, therefore, essential to extend mushrooms' shelf-life. However, some of the preservation methods change the chemical composition of mushrooms and, consequently, have effect on their nutritional value, bioactive properties and organoleptic characteristics. This paper aims to critically update and discuss the existing information about the effect of postharvest preservation methods on nutritional value and bioactive properties of edible mushrooms. It was given preference to publications within the last five years.

\section{Nutritional value of mushrooms}

Mushrooms have a high nutritional value. They are a good source of proteins, dietary fibres, vitamins, minerals and phenolic compounds with antioxidant activity. Furthermore, mushrooms have a low-fat content (composed mostly by unsaturated fatty acids) and a low energetic density (Cheung, 2010; Guillamón et al., 2010; Kalač, 2013; Valverde, Hernández-Pérez, \& Paredes-López, 2015).

The mushrooms chemical composition varies considerably among and within species (Valverde et al., 2015). The variability within species is higher in cultivated than in wild mushrooms (Kalač, 2013). Possibly, this occurs due to the great variability of substrate composition. Hoa, Wang, and Wang (2015) demonstrated that there is a negative correlation between high protein content of mushrooms and low $\mathrm{C} / \mathrm{N}$ ratio of the substrate. Besides substrate composition, the cultivation method and stage of harvesting also have an impact on mushrooms chemical composition (Valverde et al., 2015).

Fresh mushrooms are composed mostly of water. According to Kalač (2013), the dry matter of mushrooms varies between 8 and 14\%. Carbohydrates represent between 50 and $65 \%$ of mushrooms' dry matter and comprise sugars and polysaccharides (Rathore et al., 2017). The main sugars of mushrooms are mannitol and trehalose (Guillamón et al., 2010). According to Kalač (2013), the median values of these two sugars in mushrooms are $2.9 \%$ and $3.9 \%$ (on dry basis), respectively. Besides mannitol and trehalose, mushrooms also contain raffinose, sucrose, glucose, fructose and xylose (Kalač, 2013; Wani et al., 2010). In its turn, the main polysaccharides present in mushrooms are glycogen (a reserve multibranched polysaccharide) and chitin (a structural polysaccharide). Mushrooms also contain glucans, mannans and pectic substances (Kalač, 2013; Valverde et al., 2015; Wani et al., 2010).

As aforementioned, mushrooms are a good source of fibre. They contain $4-9 \%$ of soluble fibre and $22-30 \%$ of insoluble fibre (on dry basis) (Cheung, 2010; Kalač, 2013). According to Manzi, Marconi, Aguzzi, and Pizzoferrato (2004), $\beta$-glucans and chitin represent 4-13\% and $25 \%$ of the total dietary fibre, respectively.

Mushrooms are considered as a very useful food product in vegetarian diets (Valverde et al., 2015). They contain more protein (20-25\%, on dry basis) than most vegetables and its biological value is higher, since the mushrooms contain the nine essential amino acids (Kalač, 2013). The limiting amino acid is methionine and the more abundant are valine, glutamine, glutamic acid, aspartic acid and arginine (Rathore et al., 2017; Valverde et al., 2015). According to Del Toro, Vega, Garín-Aguilar, and Lara (2006), the net protein utilization (NPU) of three Pleurotus spp. strains is between 84 and $87 \%$. These values are higher than NPU of cereals like wheat (60\%) and rice (82\%) and are similar to eggs (87\%) (Del Toro et al., 2006).

Mushrooms contain a low amount of fat (2-3\% on a dry basis) and are mostly composed of unsaturated fatty acids (Kalač, 2013). According to Kalač (2013), linoleic (C18:2c,n-6) and oleic acids (C18:1c,n-9) represent more than two-thirds of the weight of all fatty acids found in mushrooms.

Mushrooms are a good source of vitamin B complex. They have high levels of niacin (B3), folates (B9) and riboflavin (B2), while thiamine (B1) and cobalamin (B12) are present in trace amounts. They also contain vitamin C and fat-soluble vitamins (A, E and D). Mushrooms are the only non-animal source of vitamin D (Guillamón et al., 2010; Rathore et al., 2017; Valverde et al., 2015). The main minerals present in mushrooms are potassium and phosphorus or magnesium, depending on the species (Guillamón et al., 2010). They also contain, in lower levels, calcium, iron, copper, zinc, manganese, selenium and sodium (Guillamón et al., 2010). The high and low contents of potassium and sodium, respectively, make mushrooms a very interesting food product in the prevention and dietary treatment of hypertension (Kalač, 2013).

The only problem that may arise from mushrooms consumption is the eventual presence of heavy metals in some substrates where mushrooms could grow, because of its capacity to accumulate them in their tissues (Guillamón et al., 2010). However, currently, the substrates for mushroom cultivation are highly controlled, as well as mushroom safety. So, nowadays, this hazard in controlled production is restrained. 


\section{Bioactive properties of mushrooms}

Mushrooms are important sources of several bioactive compounds with an enormous variety of chemical structures (Sande et al., 2019; Taofiq, Martins, Barreiro, \& Ferreira, 2016). These bioactive compounds have been classified as important contributors to the different therapeutic properties, namely antitumor, anti-inflammatory, anti-diabetic, antiallergic, immunomodulating, cardiovascular protector, anticholesterolemic, detoxification, hepatoprotective, antimicrobial, antioxidant and prebiotic activities (Barros, Cruz, Baptista, Estevinho, \& Ferreira, 2008; Fernandes, Antonio, Barreira, et al., 2012; Heleno, Martins, Queiroz, \& Ferreira, 2015; Valverde et al., 2015). The history of the mushroom collection and consumption dates back to ancient times and most of their claimed therapeutic effects were largely based on traditional and empirical knowledge of the local communities, as evidenced by findings from several ethnomycological surveys and data (Lau \& Abdullah, 2017; Liu et al., 2018). Because of their potential beneficial effects on human health, they have become increasingly attractive as functional foods and this has been translated in the increase in commercial cultivation of several edible mushrooms. The global mushroom market was worth around 35 billion USD in 2015 and it is expected to reach up to 60 billion USD by 2021, with a compound annual growth rate (CAGR) of 9.2\% (Mingyi, Belwal, Devkota, Li, \& Luo, 2019).

Beside their consumption due to their bioactive properties, the demand from the food industry for novel functional ingredients or bioactive compounds to be widely applied in the development of functional food formulation has also increased the interest in several mushroom species. Numerous bioactive compounds exist in mushrooms include polysaccharides such as $\beta$-glucans, proteins, polyphenols, steroids, terpenes, hydrolytic and oxidative enzymes, among others (Taofiq et al., 2016). Some of the common high (e.g. polysaccharide) and low (e.g. terpenes and polyphenols) molecular weight compounds found in mushrooms are shown in Fig. 1.

Most research studies conducted on the pharmacological potential of mushrooms are mainly focused on crude extracts. Nevertheless, it is also important to identify the bioactive compounds responsible for each of the ascribed bioactivities. Extraction and isolation of these bioactive compounds from mushrooms are well-established processes and some of the most conventional methods used include maceration, hydrodistillation, pressing, infusion, percolation, and Soxhlet extraction, that are time-consuming and require a large amount of solvents (Taofiq et al., 2019). Several novel and more efficient extraction techniques, such as microwave assisted extraction (MAE), ultrasound assisted extraction (UAE), supercritical fluid extraction (SFE) and subcritical water extraction (SWE) are now being applied, offering faster and efficient extraction with environmentally friendly properties (Oludemi et al., 2018; Pinela et al., 2018). Advancement in biomolecular tools such as mass spectrometry (MS), nuclear magnetic resonance (NMR) spectroscopy, chromatography, use of animal and cell-based models, and clinical trials have made the market for pharmacological formulations derived from mushrooms grow tremendously over the last couple of years.

Many studies have demonstrated the potential of mushroom extracts and their individual metabolites as anticancer agents, mainly based on their ability to inhibit cancer cells growth in vitro. Some preliminary findings are available, but the nature of cytotoxic component in<smiles>COc1cc(/C=C/C(=O)O)cc(OC)c1O</smiles><smiles>O=C(O)/C=C/c1ccccc1</smiles><smiles>O=C(O)/C=C/c1ccc(O)cc1</smiles>

Sinapic acid<smiles>CCC(=O)C[C@H](C)[C@@]1(C)C[C@H](O)[C@]2(C)C3=C(C(=O)C[C@]21C)[C@@]1(C)CCC(=O)C(C)(C)[C@@]1(C)C[C@H]3O</smiles><smiles>CCC(=O)O</smiles>
言

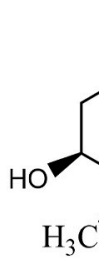<smiles>CC(=O)CC(=O)C1=CCC[C@]2(C)C(C)(C)CCC[C@]12C</smiles><smiles>CO[C@H](C)[C@@]1(C)CC[C@H]1[C@H](C)CC(=O)C[C@@H](C)C(=O)O</smiles>

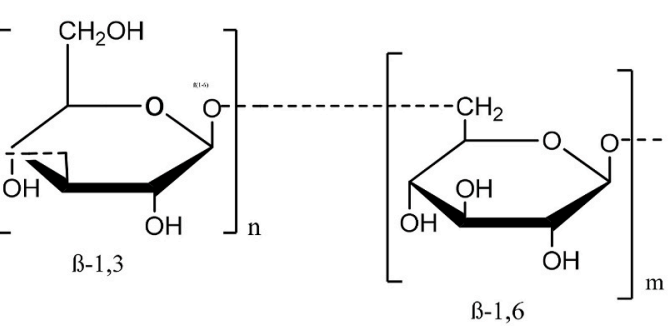

B-D-glucan<smiles>O=c1cc(O)cc(/C=C/c2ccc(O)c(O)c2)o1</smiles>

Hispidin

Fig. 1. Selected chemical structure of common bioactive metabolites present in mushrooms. 
mushrooms and the underlying mechanism of action are still yet to be fully elucidated. Most polysaccharides have been reported to present antitumor activity against various cancer cells by either directly inhibiting the growth of tumour cells, inducing apoptosis and autophagy, causing changes in cell cycle and increase expression of tumour suppressor genes (Chakraborty et al., 2019; Mingyi et al., 2019). Most recent advancement in the use of bioactive metabolites from mushroom, with anticancer properties, was reported by Shimizu et al. (2016): Agarol, an ergosterol derivative from Agaricus blazei, was found to induce caspase-independent apoptosis in human cancer cells. A low molecular weight polysaccharide isolated from A. blazei was also found to suppress the expression of tumour necrosis factor $\alpha$ (TNF- $\alpha$ ) stimulated E-selectin protein, making it a promising therapeutic agent against E-selectin-mediated neoplasm metastasis (Yue et al., 2012). A novel polysaccharide from Ganoderma atrum exerts antitumor activity by activating mitochondria-mediated apoptotic pathway; mainly by enhancing mitochondrial cytochrome $c$ release and intracellular reactive oxygen species (ROS) production, elevation of p53 and Bax expression, downregulation of $\mathrm{Bcl}-2$, and the activation of caspase-9 and -3 (Zhang, Nie, Huang, Feng, \& Xie, 2014).

Mushrooms have also been highlighted as alternative sources of antiinflammatory biomolecules mainly assessed by the nitric oxide assay, TNF- $\alpha$ inhibition in lipopolysaccharide (LPS) activated macrophage cells, measurement of inhibition of expression of inducible nitric oxide synthase (iNOS), cyclooxygenase-2 (COX-2) and other pro-inflammatory mediator using cytokine enzyme linked immunosorbent assay (ELISA) kit and cyclooxygenase-1 (COX-1) and COX-2 catalysed prostaglandin biosynthesis assay (Taofiq et al., 2016). These biomolecules mainly present anti-inflammatory activity by inhibiting NF-kB and cyclooxygenase pathways related with the expression of many inflammatory mediators. Mushrooms extracts and their individual metabolites have been shown to activate the macrophage, splenocyte, and thymocyte, in vitro, and these observations pointed to their potential immunomodulatory effect, which, nevertheless, requires further validation in animal models.

Phenolic compounds, terpenoids, tocopherol, and carotenoids have been identified to be the most important contributors to the radical scavenging activity extensively studied and documented for mushroom species belonging to the Pleurotus, Agaricus, Ganoderma and Lentinula genus. They are also good lipid peroxidation inhibitors, hydroxyl radical scavengers, and nitric oxide inhibitors (Rathore et al., 2017). Mushrooms, like other organisms, secrete antimicrobial biomolecules in order to thrive and survive in the environment. These mushrooms have been exploited as sources of bioactive compounds displaying broad-spectrum antimicrobial activities against Gram-positive, Gram-negative bacteria and fungal strains (Alves et al., 2013; Reis, Martins, Vasconcelos, Morales, \& Ferreira, 2017). Edible mushrooms are also applied in the prevention of atherosclerosis due to their low-fat content and are important sources of biomolecules such as ergosterol, eritadenine and $\beta$-glucans that are inhibitors of $\beta$-Hydroxy $\beta$-methylglutaryl-CoA (HMG-CoA) reductase. This is the rate-limiting enzyme in the endogenous cholesterol biosynthesis pathway; therefore, mushrooms present a cholesterol lowering potential (Roncero-Ramos \& Delgado-Andrade, 2017). Many studies have demonstrated the potential beneficial effect of biomolecules obtained from mushrooms in preventing or delaying the course of diseases caused by oxidative stress, making them a therapeutically stronger nutraceutical ingredient for combating and suppressing the severity of several degenerative diseases. At present, several scientific data on the nutritional attributes, bioactive composition, biological properties, and toxicity of several mushrooms have been well elaborated. Herein, we sought (i) to identify the impact of several postharvest preservation treatments on mushroom nutritional profile and bioactive properties (ii) identify gaps in the present research trends, and, finally, to propose ideas for further research.

\section{Preservation methods}

According to the literature, mushrooms preservation methods can be classified into three categories: thermal (drying and freezing), chemical (washing solutions, edible coatings and films) and physical (packing, irradiation, pulsed electric field and ultrasound) processes (Zhang et al., 2018).

\subsection{Thermal processes}

\subsubsection{Drying}

Drying is a frequent and the first preservation method used on mushrooms (Fernandes, Barros, et al., 2013; Zhang et al., 2018). The goal of this process is to reduce the moisture content (until, normally, around 13\%), which prevents: microbial growth; enzymatic or non-enzymatic reactions; and physiological and morphological damages (Piskov et al., 2020; Shishir et al., 2019; Xu et al., 2019).

In general, the quality of the dried mushrooms is evaluated by several factors, such as colour, rehydration rate, texture, flavour and the nutrition quality, which is mainly assessed regarding the protein and total sugar content (Xu et al., 2019). There are several techniques for drying edible mushrooms including: natural air drying, solar drying, hot air drying (HAD), thin layer drying, vacuum drying (VD), freeze-drying (FD), microwave drying (MD) or a combination of various technologies to improve the drying efficiency and product quality (Hu, Feng, Huang, Ibrahim, \& Liu, 2020; Zhang et al., 2018). Dried mushrooms have a more intense flavour comparing to fresh ones, however, their nutrients and bioactive compounds can be easily altered during drying (Fan, Li, Deng, \& Ai, 2012; Hu et al., 2020; Pei et al., 2016).

The most used drying method is HAD, though its disadvantages are the high temperatures and high dehydration times (Wu et al., 2015). Moreover, these disadvantages frequently cause heat damage, leading to products with textural changes (increased hardness and chewing and decreased cohesion and elasticity), browning, an unsatisfactory flavour, and a loss of nutritional value (Qi, Zhang, Mujumdar, Meng, \& Chen, 2014; K.; Zhang et al., 2018). The main effects of different drying techniques on nutrients and bioactive compounds of edible mushrooms are summarized in Table 1.

The use of high temperatures during drying of mushrooms generally changes the profile of phenolic and organic acids and decrease the polysaccharides content (Gąsecka et al., 2020). This is due to the conversion of polysaccharides into oligosaccharides and to the Maillard reactions. Besides, the high temperature may promote proteolysis, which, consequently, increases the level of free amino acids. However, Tian, Zhao, Huang, Zeng, and Zheng (2016) reported that the decrease in protein and uronic acid content did not vary significantly between fresh and L. edodes mushrooms dried by HAD, VD and MVD (microwave vacuum drying). Techniques such as VD and MVD, where lower temperatures are used, may avoid protein denaturation and the vacuum may inhibit oxidation of uronic acid (Tian et al., 2016).

According to Tian et al. (2016) the content of vitamin B12 in L. edodes mushrooms dried by VD, HAD and MVD increased in comparison to fresh ones. However, the mechanism that causes this increase is not yet understood. On the other hand, MD caused a loss of vitamin B12 content and it was reported that microwave heating deteriorated vitamin B12 molecules (Tian et al., 2016). Concerning vitamin D, Tian et al. (2016) reported that the content of this micronutrient in L. edodes mushrooms dried by MVD, VD, HAD and MD were $15.11 \%, 18.24 \%$, $24.75 \%$ and $32.62 \%$ lower than in fresh samples, respectively. On the other hand, Sławińska et al. (2016) found that HAD did not cause statistically significant changes in vitamin D content of $A$. bisporus, $P$. ostreatus and $L$. edodes mushrooms, previously subjected to UVB irradiation. In this context, more studies are required to clarify the effect of drying on vitamin D content. In dried mushrooms, the increase of vitamin D content through UVB irradiation could be performed before or after the drying process (HAD or FD) (Sławińska et al., 2016). The same 
Table 1

Main effects reported on some studies about drying treatment on mushrooms' nutrition value, bioactive compounds and bioactive properties.

\begin{tabular}{|c|c|c|c|c|c|}
\hline $\begin{array}{l}\text { Mushrooms } \\
\text { species }\end{array}$ & Drying systems & Nutrients & Bioactive compounds & Bioactive properties & References \\
\hline A. bisporus & $\begin{array}{l}\text { Freeze drying }\left(40{ }^{\circ} \mathrm{C} \text {, for } 5\right. \\
\text { h) and freeze drying } \\
\text { combined with microwave } \\
\text { vacuum drying }(60 \mathrm{~W} / \mathrm{g} \text {, for } \\
9 \mathrm{~min})\end{array}$ & - & $\begin{array}{l}\text { FD and FMVD processes changed } \\
\text { mushrooms' volatile profile and } \\
\text { consequently their flavour. }\end{array}$ & - & $\begin{array}{l}\text { Pei et al. } \\
\text { (2016) }\end{array}$ \\
\hline $\begin{array}{l}\text { Ganoderma } \\
\text { lucidum }\end{array}$ & $\begin{array}{l}\text { Hot air drying }\left(60^{\circ} \mathrm{C}\right) \text {, } \\
\text { vacuum drying }\left(60^{\circ} \mathrm{C}\right) \text { and } \\
\text { freeze drying }\left(-30^{\circ} \mathrm{C}\right)\end{array}$ & - & - & $\begin{array}{l}\text { FD and VD samples had higher } \\
\text { scavenging effects on hydroxyl } \\
\text { radicals, superoxide radicals and } \\
\text { DPPH free radical, and stronger } \\
\text { reducing power than HAD samples. } \\
\text { FD sample showed a stronger } \\
\text { antioxidant capacity than VD and } \\
\text { HAD samples in FRAP system. }\end{array}$ & $\begin{array}{l}\text { Fan et al. } \\
(2012)\end{array}$ \\
\hline $\begin{array}{l}\text { Hypsizygus } \\
\text { marmoreus }\end{array}$ & $\begin{array}{l}\text { Hot air drying }\left(60^{\circ} \mathrm{C} \text {, for } 13\right. \\
\mathrm{h}) \text {, vacuum drying }\left(60^{\circ} \mathrm{C} \text {, }\right. \\
\text { for } 11 \mathrm{~h}) \text {, microwave } \\
\text { vacuum drying }(1000 \mathrm{~W} \text {, for } \\
5 \mathrm{~min}) \text { and freeze drying } \\
\left(-45^{\circ} \mathrm{C} \text {, for } 9 \mathrm{~h}\right)\end{array}$ & $\begin{array}{l}\text { MVD process showed the highest } \\
\text { retention of total sugar content. }\end{array}$ & $\begin{array}{l}\text { FD was the treatment that showed } \\
\text { better preservation of organic acids } \\
\text { compounds and flavour nucleotides, } \\
\text { which had the values most like } \\
\text { fresh. VD and FD are interesting } \\
\text { drying methods for obtaining a } \\
\text { higher retention rate of non-volatile } \\
\text { taste components. }\end{array}$ & - & $\begin{array}{l}\text { Wu et al. } \\
\text { (2015) }\end{array}$ \\
\hline $\begin{array}{l}\text { Leccinum } \\
\text { scabrum } \\
\text { (Bull.) Gray }\end{array}$ & $\begin{array}{l}\text { Hot air drying }\left(20^{\circ} \mathrm{C} \text {, for } 48\right. \\
\text { h; } 40^{\circ} \mathrm{C} \text {, for } 12 \mathrm{~h} ; 70^{\circ} \mathrm{C} \text {, for } \\
7 \mathrm{~h})\end{array}$ & $\begin{array}{l}\mathrm{HAD} \text { at } 70^{\circ} \mathrm{C} \text { reduced the content } \\
\text { of } \mathrm{Ca}, \mathrm{K}, \mathrm{Mg} \text {, Na and } \mathrm{P} \text {. }\end{array}$ & $\begin{array}{l}\text { HAD decreased the total phenolic } \\
\text { compounds, ergosterol and organic } \\
\text { acids contents. Reductions were } \\
\text { higher in HAD at } 70{ }^{\circ} \mathrm{C} \text {. For } \\
\text { instance, HAD at } 70{ }^{\circ} \mathrm{C} \text { reduced the } \\
\text { total phenolic content by } 40 \% \text {. }\end{array}$ & $\begin{array}{l}\text { The DPHH and ABTS scavenging } \\
\text { activity was lower in dried } \\
\text { mushroom. }\end{array}$ & $\begin{array}{l}\text { Gąsecka } \\
\text { et al. (2020) }\end{array}$ \\
\hline \multirow[t]{3}{*}{ L. edodes } & $\begin{array}{l}\text { Hot air drying }\left(70^{\circ} \mathrm{C}\right) \text {, } \\
\text { microwave drying }(539 \mathrm{~W} \text {, } \\
\text { for } 18 \mathrm{~min}) \text {, vacuum drying } \\
\left(60^{\circ} \mathrm{C} \text {, for } 15 \mathrm{~h}\right) \text {, and } \\
\text { microwave vacuum drying } \\
(15 \mathrm{~W} / \mathrm{g} \text {, for } 13 \mathrm{~min})\end{array}$ & $\begin{array}{l}\text { During drying treatments, protein } \\
\text { and uronic acid contents did not } \\
\text { vary significantly. Regarding } \\
\text { vitamins, drying treatments } \\
\text { caused a loss of vitamin D value } \\
\text { compared with fresh mushrooms, } \\
\text { but HAD and VD methods } \\
\text { increased Vitamin B12 content. } \\
\text { Drying treatments increased the } \\
\text { free amino acids content with } \\
\text { greater rise in MVD process. }\end{array}$ & $\begin{array}{l}\text { MVD got the highest retention of } \\
\text { polysaccharides content. MD had } \\
\text { the lowest soluble polysaccharide } \\
\text { content because high microwave } \\
\text { power alone caused a severe } \\
\text { increase in product temperature. } \\
\text { Drying increased the total number } \\
\text { and amount of sulphur and volatile } \\
\text { compounds in mushroom. }\end{array}$ & - & $\begin{array}{l}\text { Tian et al. } \\
\text { (2016) }\end{array}$ \\
\hline & $\begin{array}{l}\text { Hot air drying (pre-drying: } \\
45,55,65 \text { or } 75^{\circ} \mathrm{C} \text {, for } 30 \\
\text { min, followed by drying at } \\
45^{\circ} \mathrm{C} \text {, for } 4.5 \mathrm{~h} \text { ) }\end{array}$ & - & $\begin{array}{l}\text { HAD-pre-dried mushrooms at } 75^{\circ} \mathrm{C} \\
\text { had the highest content of aroma } \\
\text { components. }\end{array}$ & $\begin{array}{l}\text { HAD-pre-dried samples showed } \\
\text { higher levels of enzyme activities } \\
\text { ( } \gamma \text {-glutamyl transferase and cysteine } \\
\text { sulfoxide lyase) and at } 75^{\circ} \mathrm{C} \text { had the } \\
\text { high content of aroma components. }\end{array}$ & $\begin{array}{l}\text { Xu et al. } \\
\text { (2019) }\end{array}$ \\
\hline & $\begin{array}{l}\text { Cold plasma hot air drying } \\
\left(50,60 \text { and } 70{ }^{\circ} \mathrm{C} \text {, for } 3 \mathrm{~h}\right)\end{array}$ & - & $\begin{array}{l}\text { CPHAD improved the phenolic } \\
\text { compounds and flavonoids } \\
\text { preservation. }\end{array}$ & $\begin{array}{l}\text { Treated mushrooms exhibited } \\
\text { better preserving of antioxidant } \\
\text { activity compared to the control. }\end{array}$ & $\begin{array}{l}\text { Shishir et al. } \\
\text { (2019) }\end{array}$ \\
\hline \multirow[t]{2}{*}{ P. ostreatus } & $\begin{array}{l}\text { Vacuum drying }\left(45^{\circ} \mathrm{C} \text {, for } 8\right. \\
\text { h) and freeze drying } \\
\left(-80^{\circ} \mathrm{C} \text {, for } 24 \mathrm{~h}\right)\end{array}$ & - & $\begin{array}{l}\text { VD was the treatment that showed } \\
\text { better preservation on the phenol } \\
\text { and flavonoids content of } \\
\text { mushroom. }\end{array}$ & $\begin{array}{l}\text { The ferric reducing ability and ABTS } \\
\text { scavenging activity were better in } \\
\text { VD, instead of the DPPH scavenging } \\
\text { capacity was better in FD. } \\
\text { Regarding in vitro gastrointestinal } \\
\text { digestion as a measure of } \\
\text { bioaccessibility index, VD } \\
\text { mushrooms performed better. }\end{array}$ & $\begin{array}{l}\text { Ucar and } \\
\text { Karadag } \\
\text { (2019) }\end{array}$ \\
\hline & $\begin{array}{l}\text { Freeze drying }\left(-50{ }^{\circ} \mathrm{C} \text {, for }\right. \\
26-27 \mathrm{~h}) \text {, hot air drying } \\
\left(55^{\circ} \mathrm{C}\right) \text {, microwave drying } \\
(200 \mathrm{~W} \text {, for } 40 \mathrm{~min}) \text { and sun } \\
\text { drying }\left(25 \pm 5{ }^{\circ} \mathrm{C} \text {, for } 3\right. \\
\text { days) }\end{array}$ & - & $\begin{array}{l}\text { MD mushroom had the largest } \\
\text { content of total phenol, total } \\
\text { flavonoids and a greater number of } \\
\text { secondary metabolites identified. }\end{array}$ & $\begin{array}{l}\text { The ferric reducing ability, reducing } \\
\text { power activity and ABTS } \\
\text { scavenging activity was better in } \\
\text { MD. The total antioxidant capacity } \\
\text { by the electrochemical method } \\
\text { scavenging activity was better in } \\
\text { HAD. Besides, FD and SD } \\
\text { mushrooms had relatively high } \\
\text { angiotensin-converting enzyme } \\
\text { inhibitory activity. }\end{array}$ & $\begin{array}{l}\text { Piskov et al. } \\
(2020)\end{array}$ \\
\hline $\begin{array}{l}\text { Stropharia } \\
\quad \text { rugoso } \\
\text { annulata }\end{array}$ & $\begin{array}{l}\text { Natural air drying } \\
\left(20-30^{\circ} \mathrm{C}\right) \text {, hot air drying } \\
\left(50^{\circ} \mathrm{C} \text {, for } 4 \mathrm{~h}\right) \text {, vacuum } \\
\text { freeze drying }\left(-35^{\circ} \mathrm{C} \text {, for }\right. \\
48 \mathrm{~h})\end{array}$ & $\begin{array}{l}\text { NAD, HAD and VFD treatments } \\
\text { did not change the contents of } \\
\text { crude protein. However, drying } \\
\text { processes increased the amino } \\
\text { acids content and decreased the } \\
\text { value of crude fat, carbohydrates } \\
\text { and total soluble sugar. NAD } \\
\text { caused the highest reduction of } \\
\text { crude fat while VFD enable the } \\
\text { better retention of carbohydrate } \\
\text { and total soluble sugar. }\end{array}$ & $\begin{array}{l}\text { VFD exhibited the highest level of } \\
\text { total organic acids, which indicated } \\
\text { that VFD was able to stabilize } \\
\text { organic acids. Also, VFD showed the } \\
\text { highest contents of total nucleotides } \\
\text { among the others drying methods. }\end{array}$ & - & $\begin{array}{l}\text { Hu et al. } \\
\text { (2020) }\end{array}$ \\
\hline
\end{tabular}




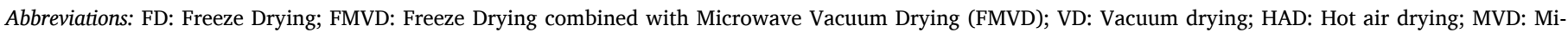
crowave Vacuum Drying; MD: Microwave drying; CPHAD Cold Plasma Hot Air Drying; SD: Sun Drying; NAD: Natural air drying; VFD: Vacuum freeze drying. - not reported.

authors also showed that the content of vitamin D in dried mushrooms (A. bisporus, $P$. ostreatus and $L$. edodes) decreased significantly during storage (in sealed plastic bags, at room temperature, in darkness). After 18 months, the vitamin D content in A. bisporus, $P$. ostreatus and L. edodes dried mushrooms was 2.07, 1.49 and 1.46 times lower than the respective values obtained immediately after drying. However, the amount of this compound compared to other products is still high, suggesting that the dried mushroom could be a good source of vitamin D (Sławińska et al., 2016).

Regarding the effect of drying on mushrooms fatty acids composition, Fernandes, Barreira, et al. (2013) reported that dried Macrolepiota procera mushrooms (HAD in an oven at $30{ }^{\circ} \mathrm{C}$ ) increased the total saturated fatty acids. Moreover, compared with fresh mushrooms, dried samples had higher total tocopherol content mainly due to increase of $\alpha$-tocopherol and $\beta$-tocopherol (Fernandes, Barreira, et al., 2013).

Fernandes, Barros, et al. (2013) also reported that dried M. procera, when compared with other different processing methods (freezing and gamma irradiation), had higher antioxidant capacity (measured by DPPH scavenging activity and $\beta$-carotene bleaching inhibition) and also presented the highest phenolic value. The heat applied during the drying process may have inactivated endogenous oxidative enzymes, which explains the increase of antioxidant activity in dried mushrooms (Fernandes, Barreira, et al., 2013).

The mushroom flavour is highly impacted by changes in the composition of amino acid and volatile compounds, where eight-carbon (C8) volatiles compounds are the major contributor to the characteristic flavour. The drying process decreases the amount of C8 volatile compounds, however, it increases the contents of sulphur and nitrogen groups compounds and, consequently, the total amount of volatile compounds, which could interfere with the mushroom flavour (Pei et al., 2016). In this way, Tian et al. (2016) reported that the MVD could be a promising method for obtaining high-quality dried mushrooms, once it helped taste-active amino acids, including aspartic acid and glutamic acid, and improved nutrient retention. Apart from MVD, FD could produce high-quality products, regarding both the nutritional value and organoleptic parameters. However, FD technique requires a high-energy consumption and high-operation cost (Wu et al., 2015; Zhang et al., 2018).

A novel laboratory-scale freeze-drying apparatus with an infrared lamp was developed by Wu, Zhang, and Bhandari (2019) and was applied for the FD of Cordyceps militaris. Results showed that drying at 40,50 and $60{ }^{\circ} \mathrm{C}$ resulted in higher retention of cordycepin and adenosine content, leading to an increase in the total phenolics, hydroxyl radical scavenging activity, and the reducing power capacity. The technology was also able to achieve faster and efficient drying when compared to conventional FD (7.21-17.78\% less drying time and $11.88-18.37 \%$ reduced energy consumption), without compromising the quality and bioactive composition of the dried product (Wu, Zhang, and Bhandari 2019). The effect on C. militaris quality of a microwave assisted pulse fluidized bed freeze-drying (MPFFD), which uses microwaves in a pulsed fluidized mode to obtain rapid heating, was evaluated (sensory parameters, volatile compounds, and antioxidant activities) and the effect was compared with FD and HAD. The FD and MPFFD samples had similar hardness and crispness, but it was higher than in HAD dried samples. Comparatively, the relative contents of ketones were $51.5 \%, 41.4 \%$ and $11.7 \%$ for FD, MPFFD and HAD samples respectively. Similarly, regarding the radical scavenging effect, FD and MPFFD samples had a better activity in the following order: FD (90.4\%) $>$ MPFFD (85.7\%) > HAD (66.8\%) (Wu, Zhang, Bhandari, and Li, 2019)

In fact, the choice of the most suitable drying method will depend on the final product properties, the complexity of the process, drying time, energy consumption and, consequently, the cost (Piskov et al., 2020).

\subsubsection{Freezing}

Freezing is one of the best methods to extend mushrooms shelf life and preserve their nutritional value during the storage period. Moreover, compared with drying, freezing allows better preservation of the mushrooms colour, aroma, texture and taste (Bernaś \& Jaworska, 2016; Fernandes, Barreira, et al., 2013).

Regarding the effect of the freezing process on mushrooms nutritional composition, Fernandes, Barros, et al. (2013) showed that frozen M. procera kept the ash and protein contents, but had a lower amount of carbohydrates, fat, total sugars, tocopherols and phenolic compounds than fresh ones. The reduction of fat content occurred due to decrease of monounsaturated and saturated fatty acids (Fernandes, Barreira, et al., 2013). Bernaś and Jaworska (2016) reported that freezing process significantly decreased the vitamins B1, B2, B6, ascorbic acid, $\alpha$-tocopherol, $\beta$-carotene and lycopene contents of A. bisporus.

Concerning the effect of freezing on preservation of mushroom nutritional composition during storage, Jaworska, Bernaś, and Mickowska (2011) found that, after 12 months, frozen samples $\left(-25^{\circ} \mathrm{C}\right)$ of $P$. ostreatus had less dry matter, protein and total amino acids than initial fresh samples. Conceivably, the total amino acids reduction occurred due to Maillard reactions. On the other hand, Bernaś and Jaworska (2016) reported that, in frozen $A$. bisporus, the length of storage ( 0,6 and 12 months, at $-20^{\circ} \mathrm{C}$ or $-30^{\circ} \mathrm{C}$ ) did not cause marked changes in the amount of total carbohydrates, protein, fat and ash. However, the same study showed that the amount of vitamins B1, B2, B6, ascorbic acid, $\alpha$-tocopherol, $\beta$-carotene and lycopene decreased significantly during frozen storage. The losses were higher in the last six months. Overall, the storage temperature $\left(-20{ }^{\circ} \mathrm{C}\right.$ or $\left.-30{ }^{\circ} \mathrm{C}\right)$ did not have a significative effect on the reduction of vitamins (Bernaś \& Jaworska, 2016).

The nutritional quality and bioactivity of frozen mushrooms are affected by the pre-treatment applied (e.g., blanching), method of freezing, frozen storage conditions, namely temperature and relative humidity, and length of storage (Bernaś \& Jaworska, 2016).

\subsection{Chemical processes}

\subsubsection{Washing solutions}

Washing A. bisporus mushrooms is necessary to remove casing soil particles. However, this process increases the mushrooms' moisture due to uptake of water, which consequently promotes their microbial deterioration. In this sense, washing A. bisporus mushrooms with antimicrobial and anti-browning solutions is common practice within the mushroom industry (Zhang et al., 2018). Thus far, the effect of various washing solutions on mushrooms postharvest preservation was studied, namely sodium metabisulfite, hydrogen peroxide, potassium sorbate, sodium salts of benzoate, ethylenediaminetetraacetic acid (EDTA), citric acid and phosphoric acids (Lagnika, Zhang, Nsor-Atindana, \& Bashari, 2014). Lagnika et al. (2014) reported that citric acid and hydrogen peroxide washing solutions decreased the respiration rate, weight loss, discolouration, firmness loss and improved the A. bisporus mushrooms microbial quality. Moreover, these results were improved when the washing solutions were combined with an ultrasound treatment (Lagnika et al., 2014).

There are only a few recent studies regarding the impact of washing solutions on mushrooms nutritional value. Sapers, Miller, Choi, and Cooke (1999) reported that hydrogen peroxide washing solution, combined with sodium erythorbate solution, did not change marked carbohydrate, protein, fat, ash and vitamin contents, and preserved the phenolic compounds of $A$. bisporus mushrooms. However, this treatment caused a loss of $19 \%$ of free amino acids. Conceivably, this loss occurred due to leaching phenomena during washing (Sapers et al., 1999). Citric acid and hydrogen peroxide washing solutions combined with 
ultrasound treatment improved the phenolic compounds and flavonoids preservation of $A$. bisporus mushrooms. However, the sole use of the solution, without the ultrasound treatment, did not have a significant effect on these bioactive compounds' preservation (Lagnika et al., 2014). Sodium metabisulphite solution also preserved the phenolic compounds and ascorbic acid of $A$. bisporus mushrooms. However, the preservation was higher in samples coated by tragacanth gum enriched with essential oils (Nasiri, Barzegar, Sahari, \& Niakousari, 2017). Cocskuner and Özdemir (2000) studied the effect of citric acid and EDTA blanching on A. bisporus mushroom mineral composition and concluded that citric acid blanching slightly decreased $\mathrm{Fe}, \mathrm{Cu}, \mathrm{Mn}$ and $\mathrm{Zn}$, but these reductions were not statistically significant. Conversely, EDTA blanching significantly decreased $\mathrm{Fe}$ and $\mathrm{Cu}$ contents.

\subsubsection{Edible coatings and films}

Edible coatings and films are thin layers of organic compounds applied on food products to extend their self-life through protection against physical, chemical and biological deterioration. The main feature that differentiates films and coatings is the presence or absence of self-supporting structures (e.g., film packaging), respectively. In the past years, the number of publications regarding edible coatings and films increased significantly. Compared with traditional packaging, this preservation method has a high environmental advantage: they do not contribute to the accumulation of residues, because coatings and films are biodegradable and, most of the times they are consumed with food. Besides, consumers are increasingly more interested in natural preservatives instead of artificial ones. Edible coating and films composition comprise biopolymers (polysaccharides and proteins), lipids, foodgrade solvents (e.g., water and ethanol), plasticizers (sorbitol or glycerol) and additives with antioxidant and antimicrobial activity, which can be from natural sources (Salgado, Ortiz, Musso, Di Giorgio, \& Mauri, 2015).

In the previous 5 years, the effect of edible coatings and, to less extent, of edible films on mushrooms preservation has been investigated by several researchers (Huang, Qian, Jiang, \& Zheng, 2019; Liu et al., 2019, 2020; Mirshekari, Madani, \& Golding, 2019; Nasiri et al., 2017, 2018; Ojeda, Sgroppo, Martín-Belloso, \& Soliva-Fortuny, 2019; Zalewska, Marcinkowska-Lesiak, \& Onopiuk, 2018; Zhang, Liu, Sun, Wang, \&

Table 2

Effects of edible coatings and films on mushrooms' nutritional value, bioactive compounds and bioactive properties.

\begin{tabular}{|c|c|c|c|c|c|}
\hline $\begin{array}{l}\text { Mushrooms } \\
\text { species }\end{array}$ & Coating or film & Nutrients & Bioactive compounds & Bioactive properties & References \\
\hline $\begin{array}{l}\text { A. bisporus was } \\
\text { stored at } 4{ }^{\circ} \mathrm{C} \text {, } \\
\text { for } 16 \text { days }\end{array}$ & $\begin{array}{l}\text { Tragacanth coating enriched } \\
\text { with Satureja khuzistanica } \\
\text { essential oil } \\
\text { Tragacanth coating enriched } \\
\text { with Zataria multiflora Boiss. } \\
\text { essential oil }\end{array}$ & $\begin{array}{l}\text { Coating treatment } \\
\text { improved the preservation } \\
\text { of ascorbic acid during } \\
\text { storage. }\end{array}$ & $\begin{array}{l}\text { Coating treatment improved the } \\
\text { preservation of phenolic compounds } \\
\text { during storage. }\end{array}$ & - & $\begin{array}{l}\text { Nasiri et al. } \\
\text { (2018) } \\
\text { Nasiri et al. } \\
\text { (2017) }\end{array}$ \\
\hline $\begin{array}{l}\text { A. bisporus was } \\
\text { stored at } 4{ }^{\circ} \mathrm{C} \text {, } \\
\text { for } 15 \text { days }\end{array}$ & Aloe vera gel coating & - & $\begin{array}{l}\text { Coated mushrooms showed the } \\
\text { highest total phenolic content, } \\
\text { during all storage period. }\end{array}$ & $\begin{array}{l}\text { Superoxide dismutase showed a } \\
\text { higher activity in coated } \\
\text { mushrooms than in controls. } \\
\text { Coating treatment improved the } \\
\text { preservation of mushrooms' } \\
\text { antioxidant capacity. }\end{array}$ & $\begin{array}{l}\text { Mirshekari } \\
\text { et al. (2019) }\end{array}$ \\
\hline $\begin{array}{l}\text { A. bisporus was cut } \\
\text { in slices and } \\
\text { stored at } 5{ }^{\circ} \mathrm{C} \text {, } \\
\text { for } 16 \text { days }\end{array}$ & $\begin{array}{l}\text { Coating containing acid } \\
\text { ascorbic-loaded chitosan/ } \\
\text { tripolyphosphate } \\
\text { nanoaggregates }\end{array}$ & $\begin{array}{l}\text { Coating treatment } \\
\text { increased the ascorbic } \\
\text { acid content and improved } \\
\text { their preservation during } \\
\text { storage. }\end{array}$ & $\begin{array}{l}\text { Coating treatment increased the } \\
\text { initial concentration of phenolic } \\
\text { compounds. However, at the end of } \\
\text { storage, the concentration of total } \\
\text { phenolic compounds in coated } \\
\text { mushrooms and controls was similar. }\end{array}$ & $\begin{array}{l}\text { Coating treatment increased } \\
\text { mushrooms' antioxidant capacity } \\
\text { and improved their preservation } \\
\text { during storage. }\end{array}$ & $\begin{array}{l}\text { Ojeda et al. } \\
(2019)\end{array}$ \\
\hline $\begin{array}{l}\text { A. bisporus was } \\
\text { stored at } 2{ }^{\circ} \mathrm{C} \text {, } \\
\text { for } 14 \text { days }\end{array}$ & $\begin{array}{l}\text { Chitosan coatings: } 0.1 \% \\
\text { chitosan in } 1 \% \text { citric acid; } \\
0.5 \% \text { chitosan in } 1 \% \text { citric acid } \\
\text { or } 0.5 \% \text { chitosan in } 1 \% \text { acetic } \\
\text { acid }\end{array}$ & - & $\begin{array}{l}\text { Coating treatments worsened } \\
\text { phenolic compounds preservation } \\
\text { during storage. }\end{array}$ & $\begin{array}{l}\text { Coating treatment with acetic acid } \\
\text { worsened the mushrooms' } \\
\text { antioxidant capacity, while the } \\
\text { other coatings did not cause } \\
\text { significant changes. }\end{array}$ & $\begin{array}{l}\text { Zalewska } \\
\text { et al. (2018) }\end{array}$ \\
\hline $\begin{array}{l}\text { A. bisporus was } \\
\text { stored at } 4{ }^{\circ} \mathrm{C} \text {, } \\
\text { for } 12 \text { days }\end{array}$ & $\begin{array}{l}\text { Chitosan and zein film } \\
\text { enriched with } \alpha \text {-tocopherol }\end{array}$ & - & $\begin{array}{l}\text { Film-treated mushrooms showed a } \\
\text { higher amount of phenolic } \\
\text { compounds at the first } 9 \text { days. }\end{array}$ & $\begin{array}{l}\text { Active film packaging increased the } \\
\text { activity of antioxidant enzymes } \\
\text { (superoxide dismutase and } \\
\text { catalase) and improved the } \\
\text { preservation of mushrooms' } \\
\text { antioxidant activity. }\end{array}$ & $\begin{array}{l}\text { Zhang et al. } \\
(2020)\end{array}$ \\
\hline $\begin{array}{l}\text { A. bisporus was } \\
\text { stored at } 4^{\circ} \mathrm{C} \text {, } \\
\text { for } 15 \text { days }\end{array}$ & $\begin{array}{l}\text { Gallic acid grafted chitosan } \\
\text { film }\end{array}$ & - & $\begin{array}{l}\text { Film-treated mushrooms showed a } \\
\text { higher amount of phenolic } \\
\text { compounds during all storage } \\
\text { period. }\end{array}$ & $\begin{array}{l}\text { The activity of antioxidant } \\
\text { enzymes (superoxide dismutase } \\
\text { and catalase) was higher in film- } \\
\text { treated mushrooms. }\end{array}$ & $\begin{array}{l}\text { Liu et al. } \\
\text { (2019) }\end{array}$ \\
\hline $\begin{array}{l}\text { L. edodes was } \\
\text { stored at } 4{ }^{\circ} \mathrm{C} \text {, } \\
\text { for } 16 \text { days }\end{array}$ & Chitosan and guar gum coating & $\begin{array}{l}\text { Coating treatment } \\
\text { improved the preservation } \\
\text { of soluble protein and } \\
\text { ascorbic acid. }\end{array}$ & - & - & $\begin{array}{l}\text { Huang et al. } \\
\text { (2019) }\end{array}$ \\
\hline $\begin{array}{l}\text { P. ostreatus was } \\
\text { stored at } 4{ }^{\circ} \mathrm{C} \text {, } \\
\text { for } 15 \text { days }\end{array}$ & $\begin{array}{l}\text { Water-soluble polysaccharide } \\
\text { from Oudemansiella radicata } \\
\text { coating }\end{array}$ & $\begin{array}{l}\text { Coating treatment } \\
\text { improved the preservation } \\
\text { of soluble protein, } \\
\text { carbohydrates and } \\
\text { ascorbic acid. }\end{array}$ & $\begin{array}{l}\text { Coating treatment increased the } \\
\text { amount of total phenolic compounds } \\
\text { and improved their preservation } \\
\text { during storage. }\end{array}$ & $\begin{array}{l}\text { Antioxidant enzymes (superoxide } \\
\text { dismutase and catalase) kept a } \\
\text { higher activity in coated } \\
\text { mushrooms than in controls. } \\
\text { Coating treatment improved the } \\
\text { preservation of mushrooms' } \\
\text { antioxidant activity. }\end{array}$ & $\begin{array}{l}\text { Liu et al. } \\
\text { (2020) }\end{array}$ \\
\hline $\begin{array}{l}\text { Pholiota nameko } \\
\text { was stored at } \\
20^{\circ} \mathrm{C} \text {, for } 9 \text { days }\end{array}$ & $\begin{array}{l}\text { Sodium alginate coating } \\
\text { enriched with thyme essential } \\
\text { oil, L-cysteine and nisin }\end{array}$ & $\begin{array}{l}\text { Coating treatment } \\
\text { improved the preservation } \\
\text { of soluble protein, soluble } \\
\text { sugar and ascorbic acid. }\end{array}$ & $\begin{array}{l}\text { The sodium alginate-based coatings } \\
\text { effectively reduced total soluble } \\
\text { phenol content relative to those of } \\
\text { the untreated control group. }\end{array}$ & $\begin{array}{l}\text { Antioxidant enzymes (superoxide } \\
\text { dismutase and catalase) kept a } \\
\text { higher activity in coated } \\
\text { mushrooms than in controls. }\end{array}$ & $\begin{array}{l}\text { Zhu et al. } \\
\text { (2019) }\end{array}$ \\
\hline
\end{tabular}

- not reported. 
Li, 2020; Zhu, Guo, Li, Song, \& Cheng, 2019). Coatings and films act as a barrier against $\mathrm{O}_{2}, \mathrm{CO}_{2}$ and $\mathrm{H}_{2} \mathrm{O}$ exchange between the food product and its surrounding atmosphere. Besides, most of them are enriched with antimicrobial preservatives and antioxidant agents, for instance, phenolic compounds, ascorbic acid and tocopherols (Liu et al., 2019; Nasiri et al., 2017, 2018; Ojeda et al., 2019; Zhang et al., 2020). Consequently, coatings and edible films decrease the respiration rate, weight loss, texture change, discolouration and increase the microbial and sensorial mushrooms quality (Huang et al., 2019; Liu et al., 2019, 2020; Mirshekari et al., 2019; Nasiri et al., 2017, 2018; Ojeda et al., 2019; Zhang et al., 2020; Zhu et al., 2019).

Concerning the effect of edible coatings and films on mushrooms nutritional composition and bioactive compounds, the major findings are the preservation of soluble protein, total sugar, ascorbic acid and total phenolic compounds (Huang et al., 2019; Liu et al., 2019, 2020; Mirshekari et al., 2019; Nasiri et al., 2017, 2018; Ojeda et al., 2019; Zhang et al., 2020; Zhu et al., 2019). For instance, Nasiri et al. (2017) and Nasiri et al. (2018) reported an increase of 31\% and 33\% in ascorbic acid and total phenolic retention, respectively, in $A$. bisporus samples coated with tragacanth gum enriched with essential oils. The main studies developed on the effects of edible coatings and films on mushrooms preservation, including an analysis of nutrients and bioactive compounds preservation, are summarized in Table 2. As far as we know, there are no studies about the effect of edible coatings and films on fatty acids profile, minerals, dietary fibre and vitamins (except vitamin C) preservation, during mushrooms storage.

Moreover, gallic acid grafted chitosan (GA-g-CS) film was utilized as a novel active packaging material for the preservation of $A$. bisporus (Liu et al., 2019). When compared to mushrooms packaged with chitosan and commercially used polyethylene film, mushrooms packaged with GA- $g$-CS film showed significantly lower respiration rate, browning degree, malondialdehyde content, electrolyte leakage rate, superoxide anion production rate and hydrogen peroxide content. The results suggested that GA-g-CS film packaging could increase the antioxidant status of $A$. bisporus, which in turn maintained the postharvest quality of mushrooms (Liu et al., 2019). Concerning the effects of most edible coatings and films on mushrooms bioactive properties (Table 2), most studies reported an enhancement in the antioxidant defence system of the coated mushroom and a higher bacteriostatic activity (Liu et al., 2019, 2020; Mirshekari et al., 2019; Ojeda et al., 2019; Zhang et al., 2020; Zhu et al., 2019).

\subsubsection{Ozone}

During their production, mushrooms are exposed to a wide range of microbial contaminations. When no antimicrobial treatment is applied, mushrooms microbial load continues to increase, during the storage period, which accelerates the postharvest mushroom deterioration. Ozone, also called triatomic oxygen, has a high antimicrobial activity due to its oxidant power (Akata, Torlak, \& Erci, 2015). Until now, few studies have been conducted on the effects of ozone on the improvement of mushrooms microbial quality. Akata et al. (2015) reported a reduction of the total microbial load and three foodborne pathogens (Salmonella enterica Typhimurium, Listeria monocytogenes, Escherichia coli O157: H7) in A. bisporus mushroom exposed to gaseous ozone (2.8 mg/L or $5.3 \mathrm{mg} / \mathrm{L}, 1 \mathrm{~h}$ ). On the other hand, Yuk, Yoo, Yoon, Marshall, and Oh (2007) reported that combined treatment of 3 ppm ozone with $1 \%$ citric acid did not significantly decrease the growth of Listeria monocytogenes and Escherichia coli O157: $\mathrm{H} 7$ in sliced F. velutipes stored at $15{ }^{\circ} \mathrm{C}$ for 10 days. Compared with other antimicrobial treatments, ozone has the advantage of leaving no toxic residues in the food product because it is rapidly degraded in oxygen. However, more studies are needed to evaluate the impact of ozone treatment on mushrooms postharvest preservation as well on their nutritional, sensorial and bioactive properties (Akata et al., 2015).

\subsubsection{Electrolyzed water}

Electrolyzed water (EW) is produced through electrolysis of a salt solution with chlorine and it is used in the food industry as a disinfectant. Just as ozone, EW has the advantage of leaving no toxic residues on food products where it is applied. When EW is diluted with tap water, it is converted into ordinary water (Aday, 2016; Wu et al., 2018). The effect of EW on edible mushrooms preservation was investigated by Aday (2016), Ding, Rahman, and Oh (2011) and Wu et al. (2018). These studies reported that the application of EW reduced the natural microflora of mushrooms (A. bisporus and P. ostreatus) and decreased the cell count of foodborne pathogens (Salmonella enterica Typhimurium, Listeria monocytogenes, Escherichia coli O157: H7 and Bacillus cereus) (Aday, 2016; Ding et al., 2011; Wu et al., 2018). Moreover, results reported by Aday (2016) and Wu et al. (2018) indicated that EW treatment combined with passive atmosphere or ultrasound preserved the colour, $\mathrm{pH}$, texture, total phenolic compounds and soluble protein, during storage.

\subsection{Physical processes}

\subsubsection{Packaging}

Appropriate packaging is one of the essential methods for preserving the quality and extending the shelf life of mushrooms. Modified atmosphere packaging (MAP) is a simple and economical packaging method to control physiological effects and microbial growth in mushrooms (Gholami, Ahmadi, \& Farris, 2017; Zhang et al., 2018). MAP consists of the change of the atmosphere inside the package influenced by the respiration rate of the product and the transfer of gases through the packaging material (Oliveira et al., 2015). The storage effect of MAP can be influenced by some factors, such as the packaging materials, gas composition, storage temperature and humidity and the surface area of the packaged sample (Zhang et al., 2018).

A low $\mathrm{O}_{2}$ concentration can potentially reduce the mushroom respiration rate controlling physiological effects, such as colour and texture changes and microbial growth (Gholami et al., 2017). Some authors recommend an atmosphere with low $\mathrm{O}_{2}$ content (between $2 \%$ and $10 \%)$ and limited $\mathrm{CO}_{2}$ content (5\% maximum). On the other hand, high $\mathrm{O}_{2}$ concentration ( $80 \%$ ) was also tested for button mushrooms and it was shown that mushrooms under these conditions showed, among other factors, a lower lipid peroxidation rate and a lower production of reactive oxygen species (Gholami et al., 2017; Joshi et al., 2018; Zhang et al., 2018). A good selection of packaging material is essential to keep the quality of packaged products. Different materials can be selected depending on the storage conditions (refrigerated or room temperature), type of mushroom presentation (sliced or whole) and packaging technology (with or without MAP, type of MAP) (Gholami et al., 2017). For example, MAP accompanied by low-temperature storage is effective in improving the shelf life of fresh mushrooms. Additionally, microperforated packaging films are commonly used to prevent the accumulation of $\mathrm{CO}_{2}$, depletion of $\mathrm{O}_{2}$, the condensation of water and high humidity levels, which accelerates microbial growth and browning (Joshi et al., 2018). Mushrooms are usually packaged in plastic films (e. g., polyethene terephthalate, PET or polyvinyl chloride, PVC), wrapped with PVC film or other stretchable films. Nevertheless, other materials have emerged, such as the use of PET with different degrees of perforation and materials obtained from renewable resources such as poly (lactic acid)/poly( $\varepsilon$-caprolactone) blend films and wheat gluten (WG) coated paper (Gholami et al., 2017; Zhang et al., 2018). It was reported that WG coated paper was the most effective to improve the shelf-life of mushrooms when compared with a stretchable PVC film, commonly used to over-wrap mushrooms (Zhang et al., 2018).

There are few publications about the effects of packaging on nutritional composition during mushroom's storage period. Donglu, Wenjian, Muinde, Xinxin, and Qiuhui (2016) analysed the effect of nanocomposite packaging material (Nano-PM) on the physicochemical characteristics and antioxidant capacity of $F$. velutipes mushrooms during 21 days of postharvest storage, at $4{ }^{\circ} \mathrm{C}$. The results showed that 
Nano-PM inhibited the weight loss, respiration rate and improved the preservation of mushroom nutrients in comparison to those packaged with the normal packaging material (Normal-PM). Besides, Nano-PM improved retention of total soluble solids and soluble protein; superoxide dismutase, catalase and peroxidase activities and decrease the levels of ROS, which contribute to the maintenance of the integrity of the mushroom biological membrane (Donglu et al., 2016). In addition, Nano-PM also inhibited the deterioration of the quality of $A$. bisporus by reducing the oxidation of lipids and proteins, contributing to the maintenance of the structure and function of the mitochondrion( $\mathrm{Wu}$, Hu, et al., 2019). This approach could be an alternative to preserve the quality of postharvest mushrooms successfully.

\subsubsection{Irradiation}

The irradiation is a non-thermal physical process that is useful to eliminate insects, microorganisms and toxins present in food products (Fernandes, Antonio, Barreira, et al., 2012). It is considered a safe, environmentally clean and energy-efficient mushroom preservation method (Fernandes et al., 2014c). Besides that, from a global point of view, irradiation preserves flavour, colour, nutrients and the taste of mushrooms, without leaving any toxic residues. Notwithstanding, irradiation might affect the mushrooms nutrients on different degrees, according to the mushroom species, complementary preservation methods used, irradiation dose and type of irradiation source (Mami, Peyvast, Ziaie, Ghasemnezhad, \& Salmanpour, 2014). The sources of irradiation can be gamma-radiation, electron beam and UV radiation (Fernandes, Antonio, Barreira, et al., 2012). Radiation doses between 1 and $2 \mathrm{kGy}$ eliminate insects, but to eliminate microorganisms, radiations up to 10 kGy might be necessary (Fernandes et al., 2014c). Any food product irradiated with doses up to $10 \mathrm{kGy}$ is considered to be safe by the World Health Organization (WHO) (Mami et al., 2014). However, consumers are still poorly receptive to consume irradiated food products.

4.3.2.1. Gamma irradiation. Gamma irradiation extends the postharvest mushrooms shelf-life through inhibition of cap opening, stalk elongation, browning and weight loss; and improvement of microbial quality (Fernandes, Antonio, Barreira, et al., 2012).

In 2012, Fernandes, Antonio, Oliveira, et al. (2012) reviewed the effect of gamma and electron beam irradiation on mushrooms chemical composition. The main studies regarding the impact of gamma irradiation on mushrooms nutritional composition, bioactive compounds and bioactive properties, published after 2012, are summarized in Table 3.

Concerning the effect of gamma irradiation on mushrooms macronutrients, the main reported disadvantage was the reduction of polyunsaturated fatty acids (Cardoso et al., 2019; Fernandes, Antonio, Oliveira, et al., 2012; Fernandes, Barreira, et al., 2013). However, the amount of unsaturated fatty acids provided by most mushrooms is considered negligible (Kalač, 2013). The effect of irradiation on mushrooms protein, carbohydrates and micronutrients, namely tocopherols and ash, varied with the mushroom species and gamma irradiation doses (Cardoso et al., 2019; Fernandes et al., 2014b, 2016, 2017; Fernandes, Barros, et al., 2013). For instance, Fernandes, Barreira, et al. (2013) reported a decrease in protein content in wild Boletus edulis and Hydnum repandum mushrooms irradiated with 1 and 2 KGy, while Fernandes,

Table 3

Effects of gamma irradiation on mushrooms' nutritional value, bioactive compounds and bioactive properties.

\begin{tabular}{|c|c|c|c|c|c|}
\hline $\begin{array}{l}\text { Mushrooms } \\
\text { species }\end{array}$ & $\begin{array}{l}\text { Irradiation } \\
\text { doses }\end{array}$ & Nutrients & Bioactive compounds & Bioactive properties & References \\
\hline $\begin{array}{l}\text { A. bisporus was } \\
\text { stored at } 5{ }^{\circ} \mathrm{C} \\
\text { for } 8 \text { days }\end{array}$ & $\begin{array}{l}1,2 \text { and } 5 \\
k G y\end{array}$ & $\begin{array}{l}\text { Overall, irradiation did not cause marked } \\
\text { changes in protein, ash, total sugars and } \\
\text { tocopherol contents. Regarding fatty acids } \\
\text { profile, it was observed that irradiation } \\
\text { increased the saturated fatty acid content } \\
\text { and decreased the amount of } \\
\text { polyunsaturated fatty acids. }\end{array}$ & $\begin{array}{l}1 \text { and } 2 \text { KGy irradiation } \\
\text { increased the ergosterol } \\
\text { content and did not cause } \\
\text { marked changes in total } \\
\text { organic acid content. }\end{array}$ & - & $\begin{array}{l}\text { Cardoso et al. } \\
\text { (2019) }\end{array}$ \\
\hline $\begin{array}{l}\beta \text {-D-glucan } \\
\text { extracted from } \\
\text { A. bisporus }\end{array}$ & $\begin{array}{l}5,10,20,30 \\
\text { and } 50 \mathrm{kGy}\end{array}$ & - & - & $\begin{array}{l}\text { There was a significant increase in the } \\
\text { antioxidant activity as the irradiation } \\
\text { dose increased from } 5 \text { to } 50 \mathrm{kGy} \text {. } \\
\text { Irradiation also increased the fat } \\
\text { binding and bile acid-binding } \\
\text { capacities. }\end{array}$ & $\begin{array}{l}\text { Khan et al. } \\
\text { (2015) }\end{array}$ \\
\hline $\begin{array}{l}\text { Wild B. pinophilus } \\
\text { and wild } \\
\text { Clitocybe } \\
\text { subconnexa }\end{array}$ & $2 \mathrm{kGy}$ & $\begin{array}{l}\text { Irradiation treatment decreased total sugar } \\
\text { and tocopherols. On the other hand, this } \\
\text { treatment increased protein and ash } \\
\text { contents. }\end{array}$ & $\begin{array}{l}\text { Irradiation treatment did not } \\
\text { change markedly phenolic } \\
\text { compounds and organic acids. }\end{array}$ & $\begin{array}{l}\text { Overall, irradiation treatment increased } \\
\text { the mushrooms' antioxidant activity. }\end{array}$ & $\begin{array}{l}\text { Fernandes et al. } \\
\text { (2016) }\end{array}$ \\
\hline $\begin{array}{l}\text { Wild dried } \\
\text { B. edulis was } \\
\text { stored for } 12 \\
\text { months }\end{array}$ & $\begin{array}{l}2 ; 6 \text { and } 10 \\
\mathrm{kGy}\end{array}$ & $\begin{array}{l}\text { Irradiation treatments improved the fat, } \\
\text { protein and ash preservation. However, } \\
\text { they were not effective regarding the total } \\
\text { sugar preservation. Concerning } \\
\text { tocopherols content, irradiation treatment } \\
\text { increased their total amount but did not } \\
\text { avoid their decrease during the storage } \\
\text { period. }\end{array}$ & $\begin{array}{l}\text { Irradiation treatments were } \\
\text { not effective regarding the } \\
\text { phenolic compounds and } \\
\text { organic acids preservation. }\end{array}$ & $\begin{array}{l}\text { Irradiation treatment increased the } \\
\text { mushrooms' antioxidant activity. } \\
\text { However, this treatment did not avoid } \\
\text { the decrease of antioxidant activity } \\
\text { during storage. }\end{array}$ & $\begin{array}{l}\text { Fernandes et al. } \\
\text { (2017) }\end{array}$ \\
\hline $\begin{array}{l}\text { Wild } B \text {. edulis and } \\
\text { wild } \\
\text { H. repandum }\end{array}$ & 1 and $2 \mathrm{kGy}$ & $\begin{array}{l}\text { Irradiation treatment decreased the } \\
\text { protein, total sugar content and } \\
\text { unsaturated fatty acids. On the other hand, } \\
\text { they increased the ash and total } \\
\text { tocopherols. }\end{array}$ & $\begin{array}{l}\text { Overall, irradiation increased } \\
\text { the amount of organic acids. }\end{array}$ & $\begin{array}{l}\text { Irradiated samples showed lower } \\
\text { scavenging activity and reducing } \\
\text { power, but higher lipid peroxidation } \\
\text { inhibition capacity. }\end{array}$ & $\begin{array}{l}\text { Fernandes, } \\
\text { Barreira, et al. } \\
\text { (2013) }\end{array}$ \\
\hline $\begin{array}{l}\text { Wild L. deliciosus } \\
\text { was stored at } \\
5{ }^{\circ} \mathrm{C} \text { for } 8 \text { days }\end{array}$ & 0.5 and $1 \mathrm{kGy}$ & $\begin{array}{l}\text { Irradiation treatments decreased ash, } \\
\text { tocopherols and polyunsaturated fatty } \\
\text { acids. On the other hand, they increased } \\
\text { the protein content. }\end{array}$ & $\begin{array}{l}0.5 \text { KGy irradiation increased } \\
\text { the amount of phenolic } \\
\text { compounds while } 1 \text { KGy } \\
\text { irradiation decreased it. }\end{array}$ & $\begin{array}{l}\text { Irradiated samples showed higher DPPH } \\
\text { radical-scavenging capacity. }\end{array}$ & $\begin{array}{l}\text { Fernandes, } \\
\text { Antonio, } \\
\text { Barreira, et al. } \\
(2012)\end{array}$ \\
\hline Wild M. procera & 0.5 and $1 \mathrm{kGy}$ & $\begin{array}{l}\text { Irradiation treatment did not cause marked } \\
\text { changes in mushrooms' nutritional } \\
\text { composition (except a slight decrease of } \\
\text { ash content and an increase in total } \\
\text { tocopherols). }\end{array}$ & $\begin{array}{l}1 \mathrm{kGy} \text { irradiation increased } \\
\text { the amount of phenolic } \\
\text { compounds. }\end{array}$ & $\begin{array}{l}\text { Irradiation treatment did not cause } \\
\text { marked changes in mushrooms' } \\
\text { antioxidant activity. }\end{array}$ & $\begin{array}{l}\text { Fernandes et al. } \\
\text { (2014b) }\end{array}$ \\
\hline
\end{tabular}

\footnotetext{
- not reported.
} 
Antonio, Barreira, et al. (2012) reported an increase in this nutrient in Lactarius deliciosus irradiated with 0.5 and $1 \mathrm{kGy}$.

Regarding bioactive compounds, namely phenolic compounds, organic acids and ergosterol, overall, gamma irradiation did not impair their content in mushrooms (Cardoso et al., 2019; Fernandes et al., 2014b, 2016; Fernandes, Antonio, Oliveira, et al., 2012). Besides that, several studies reported an improvement of antioxidant activity in gamma irradiated mushrooms (Fernandes et al., 2016; Fernandes, Antonio, Oliveira, et al., 2012; Khan et al., 2015).

4.3.2.2. Electron beam irradiation. Electron beam irradiation is produced through generators that accelerate electrons close to the velocity of light. Compared with gamma irradiation, electron beam irradiation is a faster process (its doses rates are higher) and can be initiated and stopped more easily. However, unlike gamma rays, electrons have a little penetrating power and, therefore, can only be used in thin packages (Fernandes et al., 2014a; Mami et al., 2014).

Electron beam irradiation extends postharvest mushrooms shelf life (Fernandes, Antonio, Barreira, et al., 2012). Irradiation doses up to 4 kGy improved the texture and colour preservation during storage (Mami et al., 2014). Regarding weight loss, the electron beam irradiation did not avoid moisture loss during storage (Duan et al., 2010; Mami et al., 2014). Mami et al. (2014) reported an increase of weight loss in A. bisporus irradiated with 1, 2 and 4 kGy, while Duan et al. (2010) did not detect significant differences between controls and A. bisporus irradiated with 1-4 kGy.

As far as we know, the effect of electron beam irradiation in edible mushrooms chemical composition and bioactive properties was only studied in fresh A. bisporus and wild dried mushrooms, namely, M. procera, B. edulis, Russula delica, Amanita caesarea, A. curtipes. The evaluated irradiation doses varied between 0.5 and $10 \mathrm{KGy}$ (Cardoso et al., 2019; Fernandes et al., 2014a, 2014c; Fernandes, Antonio, Barreira, et al., 2012; Fernandes, Barreira, Antonio, Morales, et al., 2015; Fernandes, Barreira, Antonio, Rafalski, et al., 2015; Mami et al., 2014). The main studies regarding the impact of electron beam irradiation on mushrooms nutritional composition, bioactive compounds and bioactive properties, published after 2012, are summarized in Table 4.

In mushrooms, sugars are the main respiration substrate. Therefore, high reductions of total sugars during storage are, usually, a consequence of high respiration rates that, in their turn, are associated with high deterioration levels (Duan et al., 2010). Some studies reported that electron beam irradiation decrease the total sugar content (Cardoso et al., 2019; Duan et al., 2010; Fernandes et al., 2014c). Besides that, Duan et al. (2010) showed that electron beam irradiation did not improve the preservation of the total sugar of $A$. bisporus irradiated with 1-4 kGys, during storage.

Concerning protein content, Duan et al. (2010) and Mami et al. (2014) reported higher preservation of this nutrient in irradiated A. bisporus during storage. Several authors reported that, just like gamma irradiation, electron beam irradiation changed mushrooms fatty acid profiles (Cardoso et al., 2019; Fernandes et al., 2014a; Fernandes et al., 2014c and Fernandes, Barreira, Antonio, Morales, et al., 2015). The decrease of polyunsaturated fatty acids can be explained by their higher susceptibility to radiolysis compared with monounsaturated and

Table 4

Effects of electron beam irradiation on mushrooms' nutritional value, bioactive compounds and bioactive properties.

\begin{tabular}{|c|c|c|c|c|c|}
\hline $\begin{array}{l}\text { Mushrooms } \\
\text { species }\end{array}$ & $\begin{array}{l}\text { Irradiation } \\
\text { doses }\end{array}$ & Nutrients & Bioactive compounds & Bioactive properties & References \\
\hline $\begin{array}{l}\text { A. bisporus was } \\
\text { stored for } 8 \\
\text { days }\end{array}$ & $\begin{array}{l}1,2 \text { and } 5 \\
\mathrm{kGy}\end{array}$ & $\begin{array}{l}\text { Overall, irradiation did not cause } \\
\text { marked changes in protein, ash and } \\
\text { tocopherols contents. However, this } \\
\text { treatment decreased total sugars } \\
\text { content and changed the fatty acid } \\
\text { profile. }\end{array}$ & $\begin{array}{l}\text { Irradiation increased the organic } \\
\text { acids and ergosterol contents. }\end{array}$ & - & $\begin{array}{l}\text { Cardoso et al. } \\
\text { (2019) }\end{array}$ \\
\hline $\begin{array}{l}\text { A. bisporus was } \\
\text { stored at } 4{ }^{\circ} \mathrm{C} \\
\text { for } 16 \text { days }\end{array}$ & $\begin{array}{l}0.5,1,2,3 \\
\text { and } 4 \mathrm{kGy}\end{array}$ & $\begin{array}{l}\text { Irradiation increased the protein } \\
\text { content and improved its preservation } \\
\text { during storage. The increase was higher } \\
\text { in samples irradiated with higher doses. } \\
\text { On the other hand, this treatment } \\
\text { decreased the vitamin C content. }\end{array}$ & $\begin{array}{l}\text { Irradiation increased the amount of } \\
\text { total phenolic compounds and } \\
\text { improved their preservation during } \\
\text { storage. The increase was higher in } \\
\text { samples irradiated with higher } \\
\text { doses. }\end{array}$ & $\begin{array}{l}\text { Irradiation increased the DPPH } \\
\text { radical-scavenging capacity and } \\
\text { improved its preservation during } \\
\text { storage. }\end{array}$ & $\begin{array}{l}\text { Mami et al. } \\
\text { (2014) }\end{array}$ \\
\hline $\begin{array}{l}\text { Wild dried } \\
\text { A. caesarea and } \\
\text { A. curtipes }\end{array}$ & $\begin{array}{l}2,6 \text { and } 10 \\
\mathrm{kGy}\end{array}$ & $\begin{array}{l}\text { Irradiation treatment increased the } \\
\text { protein, ash and tocopherols contents. } \\
\text { However, it changed fatty acids profile. } \\
\text { Regarding total sugars, the results were } \\
\text { different in both mushrooms. They } \\
\text { increased in irradiated } A \text {. caesarea and } \\
\text { decreased in irradiated } A \text {. curtipes. }\end{array}$ & $\begin{array}{l}\text { Overall, irradiation increased } \\
\text { phenolic compounds but decreased } \\
\text { the organic acids content (except in } \\
\text { A. curtipes). }\end{array}$ & $\begin{array}{l}\text { Irradiation increased the mushrooms' } \\
\text { antioxidant activity (DPPH radical- } \\
\text { scavenging capacity, reducing power, } \\
\text { TBARS formation inhibition and } \\
\beta \text {-carotene bleaching inhibition } \\
\text { capacities). }\end{array}$ & $\begin{array}{l}\text { Fernandes, } \\
\text { Barreira, } \\
\text { Antonio, } \\
\text { Rafalski, et al. } \\
\text { (2015) }\end{array}$ \\
\hline $\begin{array}{l}\text { Wild dried } \\
\text { B. edulis and } \\
\text { R. delica }\end{array}$ & $\begin{array}{l}2,6 \text { and } 10 \\
\mathrm{kGy}\end{array}$ & $\begin{array}{l}\text { Irradiation decreased the protein, total } \\
\text { sugar and ash content. Besides that, } \\
\text { irradiation changed the fatty acids } \\
\text { profile and increase tocopherols } \\
\text { content. }\end{array}$ & $\begin{array}{l}\text { Irradiation increased phenolic } \\
\text { compounds but decreased the } \\
\text { amount of organic acids. }\end{array}$ & $\begin{array}{l}\text { Irradiation improved the lipid } \\
\text { peroxidation inhibition capacity. } \\
\text { Regarding DPPH radical-scavenging } \\
\text { capacity and reducing power, the } \\
\text { irradiation effect varied depending on } \\
\text { mushroom species and irradiation } \\
\text { dose. }\end{array}$ & $\begin{array}{l}\text { Fernandes et al. } \\
(2014 \mathrm{c})\end{array}$ \\
\hline $\begin{array}{l}\text { Wild dried } \\
\text { M. procera was } \\
\text { stored for } 12 \\
\text { months }\end{array}$ & $\begin{array}{l}0.5,1 \text { and } 6 \\
k G y\end{array}$ & $\begin{array}{l}\text { Overall, irradiation did not cause } \\
\text { marked changes in carbohydrates, total } \\
\text { sugar, protein and ash. However, this } \\
\text { treatment changed the fatty acids } \\
\text { profile and decreased the tocopherols } \\
\text { content. }\end{array}$ & - & $\begin{array}{l}\text { Irradiation decreased the } \\
\text { mushrooms' antioxidant activity } \\
\text { (DPPH radical-scavenging capacity, } \\
\text { reducing power and lipid } \\
\text { peroxidation inhibition capacity). }\end{array}$ & $\begin{array}{l}\text { Fernandes et al. } \\
\text { (2014a) }\end{array}$ \\
\hline $\begin{array}{l}\text { Wild dried } \\
\text { B. edulis } \\
\text { Wild dried } \\
\text { M. procera }\end{array}$ & $\begin{array}{l}2,6 \text { and } 10 \\
\mathrm{kGy} \\
0.5,1 \text { and } 6 \\
\mathrm{kGy}\end{array}$ & $\begin{array}{l}10 \mathrm{kGy} \text { irradiation decreased the } \\
\text { insoluble and total fiber contents of } \\
B . \text { edulis. Regarding } M \text {. procera, all } \\
\text { irradiation doses decreased the } \\
\text { insoluble and total fiber contents. The } \\
\text { increases were higher in samples } \\
\text { irradiated with higher doses. }\end{array}$ & - & - & $\begin{array}{l}\text { Fernandes, } \\
\text { Barreira, } \\
\text { Antonio, } \\
\text { Morales, et al. } \\
\text { (2015) }\end{array}$ \\
\hline
\end{tabular}

- not reported. 
saturated fatty acids (Fernandes, Barreira, Antonio, Rafalski, et al., 2015).

Regarding bioactive compounds, the main advantage of electron beam irradiation was the increase of phenolic compounds (Fernandes et al., 2014a, 2014c; Fernandes, Barreira, Antonio, Rafalski, et al., 2015; Mami et al., 2014). However, according to Fernandes et al. (2014c) and Fernandes, Barreira, Antonio, Rafalski, et al. (2015), wild dried mushrooms submitted to electron beam irradiation treatment had lesser organic acids content than non-irradiated controls. Overall, the electron beam irradiation increased the antioxidant activity of mushrooms (Fernandes et al., 2014c; Fernandes, Barreira, Antonio, Rafalski, et al., 2015; Mami et al., 2014).

4.3.2.3. UV irradiation. Unlike gamma and electron beam irradiation, the main function of UV irradiation within the mushroom industry usually is not to extend their postharvest shelf life, but rather to increase their nutritional value, through the increase of its vitamin D content (Huang, Lin, \& Tsai, 2015). Vitamin D has an impact on bone and muscle health, cancer disease, cardiovascular diseases, liver function, atopic dermatitis, obesity, depression and diabetes (Taofiq, Fernandes, Barros, Barreiro, \& Ferreira, 2017).

Wild mushrooms are a good source of vitamin D. For example, a serving $(100 \mathrm{~g})$ of wild $B$. edulis provides enough vitamin $\mathrm{D}(58.7 \mu \mathrm{g})$ to achieve the recommended daily allowance (RDA) (15 $\mu \mathrm{g}$ ) (Simon, Phillips, Horst, \& Munro, 2011). In mushrooms, the vitamin D production occurs due to a photochemical reaction, catalysed by UV radiation from sunlight, which converts ergosterol (fungal sterol) into vitamin $\mathrm{D}_{2}$ (Taofiq et al., 2017). Although, when cultivated mushrooms grew in the darkness, they did not have or had negligible amount of vitamin D (Guillamón et al., 2010). Recently, UV light sources have been incorporated in mushroom production processes to simulate sunlight exposure and promote vitamin D production (Huang et al., 2015; Taofiq et al., 2017). For instance, Simon et al. (2011) and Huang et al. (2015) reported an increase of vitamin D levels of $747 \%$ in A. bisporus and 438-530\% in Pleurotus spp. (golden oyster, oyster and pink oyster) when these were exposed to UVB irradiation $\left(1.08 \mathrm{~J} / \mathrm{cm}^{2}\right.$ and $0.259 \mathrm{~J} / \mathrm{cm}^{2}$, respectively).

As far as we know, there is little information about the impact of UV irradiation on other nutrients and bioactive substances present in mushrooms (Huang et al., 2015; Simon et al., 2011). Simon et al. (2011) analysed the chemical composition of $A$. bisporus exposed to UVB irradiation $\left(1.08 \mathrm{~J} / \mathrm{cm}^{2}\right)$ and concluded that UV-B irradiation exposure did not cause significant changes in carbohydrates, fat, fatty acids profile, protein, amino acids profile, ash and water-soluble vitamin content. On the other hand, Huang et al. (2015) reported changes in soluble polysaccharides and antioxidant compounds content (phenolic compounds and flavonoids) of Pleurotus spp. (golden oyster, oyster and pink oyster irradiated with UV-B $\left(0.259 \mathrm{~J} / \mathrm{cm}^{2}\right)$. It is important to emphasize that, even though UV irradiation may lead to nutritional losses (more studies are required to confirm this fact), these irradiated mushrooms provide an alternative to animal source derived vitamin $\mathrm{D}$ and can be an attractive option for vegans or lactose intolerant individuals, taking into account that most vitamin D fortified foods are based on dairy or related products (Huang et al., 2015). Pulsed irradiated (60 pulses) freeze-dried $P$. ferulae mushrooms contributed to $65 \mu \mathrm{g} / \mathrm{g}$ dry weight of vitamin $\mathrm{D}_{2}$ and were able to increase bone density in osteoporotic mice after 23 weeks of treatment (Chen et al., 2015).

\subsubsection{Pulsed electric field and ultrasound}

Pulsed electric field (PEF) is a non-thermal technique used to preserve the quality of food. The treatment with PEF creates transient or permanent pores in the microbial cell membranes, leading to irreversible cell disruption, which helps to inactivate the microorganisms (Zhang et al., 2018). This phenomenon, recognized as electroporation, induces lethal damage to cells and allows electrophoretic movement of charges between cellular compartments (Dellarosa, Frontuto, Laghi, Dalla, \& Lyng, 2017; Parniakov, Deng, Patras, \& Rosello, 2016). Dellarosa et al. (2017) reported that the PEF applied in combination at low and high temperature, can redistribute inter-cellular water to extracellular spaces in mushrooms' stalk tissue.

There are very few studies about PEF as a postharvest preservation method of mushrooms and its influence on the nutritional composition. Dellarosa et al. (2017) reported that polysaccharides, mainly those that constitute the mushroom cell wall, were modified by PEF process in their morphology and molecular weight.

Ultrasound is a promising technique applied in food technology for processing, preservation and extraction. It improves the food quality, reduced chemical and physical damages and keeps the characteristics of the fresh product (colour, consistency, flavour, and nutrients) (Jiang, Zhang, \& Xu, 2020; Lagnika, Zhang, \& Mothibe, 2013; Li et al., 2017). The application of ultrasound in the preservation process is based on an ultrasonic wave that propagates through materials, causing a rapid series of alternate compressions and rarefactions. This results in the production of numerous microscopic channels and cavitation effect (Zhao, Yi, Bi, Chen, \& Zhou, 2018). The cavitation generates local heat and pressure that disintegrate biological cells and can create free radicals that neutralize enzymes such as lipoxygenase, peroxidase, polyphenol oxidase (Jiang et al., 2020; Lagnika et al., 2013; Zhang et al., 2018; Z.; Zhang, Liu, Liu, Li, \& Jiang, 2016). The ultrasound frequency to neutralize microorganisms or enzymes ranges from $20 \mathrm{kHz}$ to $10 \mathrm{MHz}$ (Jiang et al., 2020; Ojha, Tiwari, \& Donnell, 2018). However, this recommended frequency range can also induce physical damage to products and lead to the free radical formation (Jambrak, Mason, Paniwnyk, \& Lelas, 2007).

In general, the ultrasound treatment on mushrooms slowed the respiration rate. Possibly, this observation occurs due to hydrogen peroxide formation in distilled water during the process, thus decreasing the oxygen levels (Lagnika et al, 2013, 2014; Li et al., 2017). Li et al. (2017) reported that the ultrasonic treatment improved the storage life of straw mushroom (Volvariella volvaceae) for $72 \mathrm{~h}$, keeping a stable colour and original odour without spoilage. The ultrasound treatment also retarded the discolouration of white mushrooms. Possibly this occurs due to the lowest polyphenol oxidase and peroxidase activities and other enzymes activities involved in respiratory pathways (slowing respiratory rate) and microbial growth inhibition (Lagnika et al., 2013; Li et al., 2017; Wu et al., 2018). Furthermore, ultrasound treatment could prolong the storage of mushroom with a beneficial appearance and physicochemical characteristics by slowing the production of malondialdehyde, a marker of lipid peroxidation that can damage the integrity of cellular membranes (Li et al., 2017).

There are few studies about the effect of ultrasound treatment on mushrooms' chemical composition. Li et al. (2017) studied the effect of ultrasound treatment on total soluble sugar and total soluble protein of straw mushroom. The total soluble sugar and protein are indicators of mushroom postharvest deterioration. After ultrasound treatment, the content of these nutrients decreased, which indicates that ultrasound caused tissue destruction ( $\mathrm{Li}$ et al., 2017). On the other hand, Zhang et al. (2016) reported that the ultrasound application had a positive effect in preserving the nutrients of $A$. bisporus mushrooms, especially for vitamin C content, possibly due to its non-thermal character. In addition, it was observed that ultrasonic waves were effective in retaining the total phenolics and flavonoids content of mushroom (A. bisporus) during refrigerated storage (Lagnika et al., 2014, 2013; Wu et al., 2018).

\section{Concluding remarks}

To extend the shelf life, improve nutritional quality, enhance bioactive properties and chemical composition of edible mushrooms, either during postharvest preservation, transportation or commercialization, several novel and emerging preservation techniques have been 
explored. This paper summarized the more recent scientific information about the effect of several preservation methods on the nutritional value, bioactive compounds and bioactive properties of mushrooms.

Freezing is one of the best methods to preserve the mushrooms nutrition value during storage. However, after a long storage, frozen mushrooms lose amino acids and vitamins (Bernaś \& Jaworska, 2016; Jaworska et al., 2011). In its turn, drying causes significant changes in texture, colour and flavour of mushrooms. Furthermore, when high temperatures are used, the degradation of polysaccharides and proteins occur. Further, research is required in order to clarify the effect of drying on vitamins D and B12.

The use of edible coatings and films tend to increase due to the associated environmental advantages compared to the use of plastic packaging. From a global point of view, those solutions have proved to preserve total sugar, ascorbic acid, total phenolic compounds and flavonoids during storage. Regarding washing solutions, the main nutritional change reported is the loss of free amino acids due to the leaching effect. Gamma and electron beam irradiation might affect the mushroom nutrients, to a different extent, according to the mushroom species, complementary preservation methods used, irradiation dose and type of irradiation source. However, from a global point of view, these treatments do not usually cause severe changes in mushrooms nutritional composition. On the other hand, UV irradiation significantly increases the amount of vitamin $\mathrm{D}$, in mushrooms.

There is scarce information about the impact of edible coatings, films, washing solutions, ozone, electrolyzed water, packaging, pulsed electric and ultrasound on mushrooms chemical composition. Compared with nutritional properties, characteristics, such as colour, texture, weight loss and microbial quality, had more influence on the consumers' purchase behaviour. In this sense, most studies about mushrooms preservation are more focused on these properties. Regarding the effect of these post-harvest preservation methods on the bioactive properties of edible mushrooms, a significant number of reports only focused on the antioxidant activity, with merely a few studies reporting the antimicrobial properties of the treated mushrooms. Hence, there is a need for more studies using other biological assays and elucidating their mechanisms of action.

However, it was difficult to draw general conclusions about the most sustainable preservation methods to preserve mushrooms' nutritional value and bioactive properties. Overall, the results in different published studies cannot be compared because the preservation methods were applied in different mushrooms species. Furthermore, even when different preservation methods were used on the same mushrooms species, it can be incorrect to compare the results from different studies because mushrooms' chemical composition varies significantly within the same species. This variability may, therefore, influence preservation.

\section{CRediT authorship contribution statement}

Sara Marçal: Writing - review \& editing, Visualization, Investigation. Ana Sofia Sousa: Writing - review \& editing, Visualization, Investigation. Oludemi Taofiq: Writing - review \& editing, Investigation. Filipa Antunes: Investigation. Alcina M.M.B. Morais: Validation. Ana Cristina Freitas: Validation. Lillian Barros: Supervision, Validation. Isabel C.F.R. Ferreira: Supervision. Manuela Pintado: Conceptualization, Supervision, Validation.

\section{Declaration of competing interest}

The authors declare no conflicts of interest.

\section{Acknowledgments}

The authors are grateful to the European Agricultural Fund for Rural Development (EAFRD), through the Rural Development Program (PDR2020), within the scope of Project MicoCoating [PDR2020-101-
031472] and European Regional Development Fund (ERDF) through the Competitiveness and Internationalization Operational Program (POCI), within the scope of project MicoBioExtract [POCI-01-0247-FEDER033939]. We would also like to thank the National Funds from FCT Fundação para a Ciência e a Tecnologia through project UID/Multi/ 50016/2019, FCT/MEC (PIDDAC) - IF/00588/2015 and FCT individual $\mathrm{PhD}$ grant number SFRH/BD/145301/2019. The authors are also grateful to FCT, Portugal for financial support through national funds FCT/MCTES to CIMO [UIDB/00690/2020] and national funding by FCT, P.I., through the institutional scientific employment programcontract for L. Barros.

\section{References}

Aday, M. S. (2016). Application of electrolyzed water for improving postharvest quality of mushroom. LWT-Food Science and Technology, 68, 44-51.

Akata, I., Torlak, E., \& Erci, F. (2015). Efficacy of gaseous ozone for reducing microflora and foodborne pathogens on button mushroom. Postharvest Biology and Technology, 109, 40-44.

Alves, M. J., Ferreira, I. C. F. R., Froufe, H. J. C., Abreu, R. M. V., Martins, A., \& Pintado, M. (2013). Antimicrobial activity of phenolic compounds identified in wild mushrooms, SAR analysis and docking studies. Journal of Applied Microbiology, 115 (2), 346-357. https://doi.org/10.1111/jam.12196

Barros, L., Cruz, T., Baptista, P., Estevinho, L. M., \& Ferreira, I. C. F. R. (2008). Wild and commercial mushrooms as source of nutrients and nutraceuticals. Food and Chemical Toxicology, 46(8), 2742-2747.

Bernaś, E., \& Jaworska, G. (2016). Vitamins profile as an indicator of the quality of frozen Agaricus bisporus mushrooms. Journal of Food Composition and Analysis, 49, $1-8$.

Cardoso, R. V. C., Fernandes, Â., Barreira, J. C. M., Verde, S. C., Antonio, A. L., GonzalézParamás, A. M., et al. (2019). Effectiveness of gamma and electron beam irradiation as preserving technologies of fresh Agaricus bisporus portobello: A comparative study. Food Chemistry, 278, 760-766.

Chakraborty, I., Sen, I. K., Mondal, S., Rout, D., Bhanja, S. K., Maity, G. N., et al. (2019). Bioactive polysaccharides from natural sources: A review on the antitumor and immunomodulating activities. Biocatalysis and Agricultural Biotechnology, 22, 101425. https://doi.org/10.1016/j.bcab.2019.101425. October.

Chang, S. T., \& Miles, P. G. (1992). Mushroom biology—a new discipline. Mycologist, 6 (2), 64-65.

Chen, S. Y., Yu, H. T., Kao, J. P., Yang, C. C., Chiang, S. S., Mishchuk, D. O., et al. (2015). Consumption of vitamin D2 enhanced mushrooms is associated with improved bone health. Journal of Nutritional Biochemistry, 26(7), 696-703. https://doi.org/10.1016/ j.jnutbio.2015.01.006

Cheung, P. C. K. (2010). The nutritional and health benefits of mushrooms. Nutrition Bulletin, 35(4), 292-299.

Cocskuner, Y., \& Özdemir, Y. (2000). Acid and EDTA blanching effects on the essential element content of mushrooms (Agaricus bisporus). Journal of the Science of Food and Agriculture, 80(14), 2074-2076.

Del Toro, G. V., Vega, R. C., Garín-Aguilar, M. E., \& Lara, H. L. (2006). Biological quality of proteins from three strains of Pleurotus spp. Food Chemistry, 94(4), 494-497.

Dellarosa, N., Frontuto, D., Laghi, L., Dalla, M., \& Lyng, J. G. (2017). The impact of pulsed electric fields and ultrasound on water distribution and loss in mushrooms stalks. Food Chemistry, 236, 94-100. https://doi.org/10.1016/j. foodchem.2017.01.105

Ding, T., Rahman, S. M. E., \& Oh, D. H. (2011). Inhibitory effects of low concentration electrolyzed water and other sanitizers against foodborne pathogens on oyster mushroom. Food Control, 22(2), 318-322.

Donglu, F., Wenjian, Y., Muinde, B., Xinxin, A., \& Qiuhui, H. (2016). Effect of nanocomposite packaging on postharvest quality and reactive oxygen species metabolism of mushrooms (Flammulina velutipes). Postharvest Biology and Technology, 119, 49-57. https://doi.org/10.1016/j.postharvbio.2016.04.012

Duan, Z., Xing, Z., Shao, Y., \& Zhao, X. (2010). Effect of electron beam irradiation on postharvest quality and selected enzyme activities of the white button mushroom, Agaricus bisporus. Journal of Agricultural and Food Chemistry, 58(17), 9617-9621.

El Sheikha, A. F., \& Hu, D. M. (2018). How to trace the geographic origin of mushrooms? Trends in Food Science \& Technology, 78, 292-303.

Fan, L., Li, J., Deng, K., \& Ai, L. (2012). Effects of drying methods on the antioxidant activities of polysaccharides extracted from Ganoderma lucidum. Carbohydrate Polymers, 87(2), 1849-1854. https://doi.org/10.1016/J.CARBPOL.2011.10.018

Fernandes, Â., Antonio, A. L., Barreira, J. C. M., Oliveira, M. B. P. P., Martins, A., \& Ferreira, I. C. F. R. (2012). Effects of gamma irradiation on physical parameters of Lactarius deliciosus wild edible mushrooms. Postharvest Biology and Technology, 74, 79-84.

Fernandes, Â., Antonio, A. L., Oliveira, M. B. P. P., Martins, A., \& Ferreira, I. C. F. R. (2012). Effect of gamma and electron beam irradiation on the physico-chemical and nutritional properties of mushrooms: A review. Food Chemistry, 135(2), 641-650.

Fernandes, Â., Barreira, J. C. M., Antonio, A. L., Morales, P., Férnandez-Ruiz, V., Martins, A., et al. (2015). Exquisite wild mushrooms as a source of dietary fiber: Analysis in electron-beam irradiated samples. LWT-Food Science and Technology, 60 (2), 855-859.

Fernandes, Â., Barreira, J. C. M., Antonio, A. L., Oliveira, M. B. P. P., Martins, A., \& Ferreira, I. C. F. R. (2014a). Combined effects of electron-beam irradiation and 
storage time on the chemical and antioxidant parameters of wild Macrolepiota procera dried samples. Food and Bioprocess Technology, 7(6), 1606-1617.

Fernandes, Â., Barreira, J. C. M., Antonio, A. L., Oliveira, M. B. P. P., Martins, A., \& Ferreira, I. C. F. R. (2014b). Effects of gamma irradiation on chemical composition and antioxidant potential of processed samples of the wild mushroom Macrolepiota procera. Food Chemistry, 149, 91-98.

Fernandes, Â., Barreira, J. C. M., Antonio, A. L., Oliveira, M. B. P. P., Martins, A., \& Ferreira, I. C. F. R. (2014c). Feasibility of electron-beam irradiation to preserve wild dried mushrooms: Effects on chemical composition and antioxidant activity. Innovative Food Science \& Emerging Technologies, 22, 158-166.

Fernandes, Â., Barreira, J. C. M., Antonio, A. L., Oliveira, M. B. P. P., Martins, A., \& Ferreira, I. C. F. R. (2016). Extended use of gamma irradiation in wild mushrooms conservation: Validation of $2 \mathrm{kGy}$ dose to preserve their chemical characteristics. LWT-Food Science and Technology, 67, 99-105.

Fernandes, Â., Barreira, J. C. M., Antonio, A. L., Rafalski, A., Oliveira, M. B. P. P., Martins, A., et al. (2015). How does electron beam irradiation dose affect the chemical and antioxidant profiles of wild dried Amanita mushrooms? Food Chemistry, 182, 309-315.

Fernandes, Â., Barreira, J. C. M., Antonio, A. L., Santos, P. M. P., Martins, A., Oliveira, M. B. P. P., et al. (2013). Study of chemical changes and antioxidant activity variation induced by gamma-irradiation on wild mushrooms: Comparative study through principal component analysis. Food Research International, 54(1), 18-25.

Fernandes, Â., Barreira, J. C. M., Günaydi, T., Alkan, H., Antonio, A. L., Oliveira, M. B. P. P., et al. (2017). Effect of gamma irradiation and extended storage on selected chemical constituents and antioxidant activities of sliced mushroom. Food Control, 72, 328-337.

Fernandes, Â., Barros, L., Barreira, J. C. M., Antonio, A. L., Oliveira, M. B. P. P., Martins, A., et al. (2013). Effects of different processing technologies on chemical and antioxidant parameters of Macrolepiota procera wild mushroom. LebensmittelWissenschaft und -Technologie- Food Science and Technology, 54(2), 493-499. https:// doi.org/10.1016/j.lwt.2013.06.027

Food and Agriculture Organization Statistical (Faostat). (2018). FAOSTAT-Data-CropsVisualized-Mushrooms and truffles. http://www.fao.org/faostat/en/\#data/QC Accessed 20 August 2020.

Gholami, R., Ahmadi, E., \& Farris, S. (2017). Shelf life extension of white mushrooms (Agaricus bisporus) by low temperatures conditioning, modified atmosphere, and nanocomposite packaging material. Food Packaging and Shelf Life, 14, 88-95. https:// doi.org/10.1016/j.fpsl.2017.09.001. August.

Guillamón, E., García-Lafuente, A., Lozano, M., Rostagno, M. A., Villares, A., Martínez, J. A., et al. (2010). Edible mushrooms: Role in the prevention of cardiovascular diseases. Fitoterapia, 81(7), 715-723.

Gąsecka, M., Siwulski, M., Magdziak, Z., Budzyńska, S., Stuper-Szablewska, K., Niedzielski, P., et al. (2020). The effect of drying temperature on bioactive compounds and antioxidant activity of Leccinum scabrum (Bull.) Gray and Hericium erinaceus (Bull.) Pers. Journal of Food Science and Technology, 57(2), 513-525. https://doi.org/10.1007/s13197-019-04081-1

Heleno, S. A., Martins, A., Queiroz, M. J. R. P., \& Ferreira, I. C. F. R. (2015). Bioactivity of phenolic acids: Metabolites versus parent compounds: A review. Food Chemistry, 173, 501-513. https://doi.org/10.1016/j.foodchem.2014.10.057

Hoa, H. T., Wang, C. L., \& Wang, C. H. (2015). The effects of different substrates on the growth, yield, and nutritional composition of two oyster mushrooms (Pleurotus ostreatus and Pleurotus cystidiosus). Mycobiology, 43(4), 423-434.

Huang, S. J., Lin, C.-P., \& Tsai, S. Y. (2015). Vitamin D2 content and antioxidant properties of fruit body and mycelia of edible mushrooms by UV-B irradiation. Journal of Food Composition and Analysis, 42, 38-45.

Huang, Q., Qian, X., Jiang, T., \& Zheng, X. (2019). Effect of chitosan and guar gum based composite edible coating on quality of mushroom (Lentinus edodes) during postharvest storage. Scientia Horticulturae, 253, 382-389.

Hu, S., Feng, X., Huang, W., Ibrahim, S. A., \& Liu, Y. (2020). Effects of drying methods on non-volatile taste components of Stropharia rugoso-annulata mushrooms. LWT - Food Science and Tecnology, 127, 109428. https://doi.org/10.1016/j.lwt.2020.109428

Jambrak, A., Mason, T. J., Paniwnyk, L., \& Lelas, V. (2007). Accelerated drying of button mushrooms, Brussels sprouts and cauliflower by applying power ultrasound and its rehydration properties. Journal of Food Engineering, 81, 88-97. https://doi.org/ 10.1016/j.jfoodeng.2006.10.009

Jaworska, G., Bernaś, E., \& Mickowska, B. (2011). Effect of production process on the amino acid content of frozen and canned Pleurotus ostreatus mushrooms. Food Chemistry, 125(3), 936-943.

Jiang, T., Luo, S., Chen, Q., Shen, L., \& Ying, T. (2010). Effect of integrated application of gamma irradiation and modified atmosphere packaging on physicochemical and microbiological properties of shiitake mushroom (Lentinus edodes). Food Chemistry, 122(3), 761-767.

Jiang, Q., Zhang, M., \& Xu, B. (2020). Application of ultrasonic technology in postharvested fruits and vegetables storage: A review. Ultrasonics Sonochemistry, 69, 105261. https://doi.org/10.1016/j.ultsonch.2020.105261. July.

Joshi, K., Warby, J., Valverde, J., Tiwari, B., Cullen, P. J., \& Frias, J. M. (2018). Impact of cold chain and product variability on quality attributes of modified atmosphere packed mushrooms (Agaricus bisporus) throughout distribution. Journal of Food Engineering, 232, 44-55. https://doi.org/10.1016/j.jfoodeng.2018.03.019

Kalač, P. (2013). A review of chemical composition and nutritional value of wildgrowing and cultivated mushrooms. Journal of the Science of Food and Agriculture, 93 (2), 209-218.

Khan, A. A., Gani, A., Shah, A., Masoodi, F. A., Hussain, P. R., Wani, I. A., et al. (2015). Effect of $\gamma$-irradiation on structural, functional and antioxidant properties of $\beta$-glucan extracted from button mushroom (Agaricus bisporus). Innovative Food Science \& Emerging Technologies, 31, 123-130. https://doi.org/10.1016/j.ifset.2015.05.006

Lagnika, C., Zhang, M., \& Mothibe, K. J. (2013). Effects of ultrasound and high pressure argon on physico-chemical properties of white mushrooms (Agaricus bisporus) during postharvest storage. Postharvest Biology and Technology, 82, 87-94. https://doi.org/ 10.1016/j.postharvbio.2013.03.006

Lagnika, C., Zhang, M., Nsor-Atindana, J., \& Bashari, M. (2014). Effects of ultrasound and chemical treatments on white mushroom (Agaricus bisporus) prior to modified atmosphere packaging in extending shelf-life. Journal of Food Science \& Technology, 51(12), 3749-3757.

Lau, B. F., \& Abdullah, N. (2017). Bioprospecting of Lentinus squarrosulus mont., an underutilized wild edible mushroom, as a potential source of functional ingredients: A review. Trends in Food Science \& Technology, 61, 116-131. https://doi.org/ 10.1016/j.tifs.2016.11.017

Li, N., Chen, F., Cui, F., Sun, W., Zhang, J., Qian, L., et al. (2017). Improved postharvest quality and respiratory activity of straw mushroom (Volvariella volvacea) with ultrasound treatment and controlled relative humidity. Scientia Horticulturae, 225, 56-64. https://doi.org/10.1016/j.scienta.2017.06.057. July.

Lin, X., \& Sun, D.-W. (2019). Research advances in browning of button mushroom (Agaricus bisporus): Affecting factors and controlling methods. Trends in Food Science \& Technology, 90, 63-75.

Liu, D., Cheng, H., Bussmann, R. W., Guo, Z., Liu, B., \& Long, C. (2018). An ethnobotanical survey of edible fungi in Chuxiong City, Yunnan, China. Journal of Ethnobiology and Ethnomedicine, 14(1), 1-10. https://doi.org/10.1186/s13002-0180239-2

Liu, Q., Kong, W., Hu, S., Kang, Y., Zhang, Y., \& Ng, T. B. (2020). Effects of Oudemansiella radicata polysaccharide on postharvest quality of oyster mushroom (Pleurotus ostreatus) and its antifungal activity against Penicillium digitatum. Postharvest Biology and Technology, 166, 111207.

Liu, J., Liu, S., Zhang, X., Kan, J., \& Jin, C. (2019). Effect of gallic acid grafted chitosan film packaging on the postharvest quality of white button mushroom (Agaricus bisporus). Postharvest Biology and Technology, 147, 39-47. https://doi.org/10.1016/j. postharvbio.2018.09.004. April 2018.

Mami, Y., Peyvast, G., Ziaie, F., Ghasemnezhad, M., \& Salmanpour, V. (2014). Improvement of shelf life and postharvest quality of white button mushroom by electron beam irradiation. Journal of Food Processing and Preservation, 38(4), 1673-1681.

Manzi, P., Marconi, S., Aguzzi, A., \& Pizzoferrato, L. (2004). Commercial mushrooms: Nutritional quality and effect of cooking. Food Chemistry, 84(2), 201-206.

Mingyi, Y., Belwal, T., Devkota, H. P., Li, L., \& Luo, Z. (2019). Trends of utilizing mushroom polysaccharides (MPs) as potent nutraceutical components in food and medicine: A comprehensive review. Trends in Food Science \& Technology, 92, 94-110. https://doi.org/10.1016/j.tifs.2019.08.009. August.

Mirshekari, A., Madani, B., \& Golding, J. B. (2019). Aloe vera gel treatment delays postharvest browning of white button mushroom (Agaricus bisporus). Journal of Food Measurement and Characterization, 13(2), 1250-1256.

Nasiri, M., Barzegar, M., Sahari, M. A., \& Niakousari, M. (2017). Tragacanth gum containing Zataria multiflora Boiss. essential oil as a natural preservative for storage of button mushrooms (Agaricus bisporus). Food Hydrocolloids, 72, 202-209.

Nasiri, M., Barzegar, M., Sahari, M. A., \& Niakousari, M. (2018). Application of Tragacanth gum impregnated with Satureja khuzistanica essential oil as a natural coating for enhancement of postharvest quality and shelf life of button mushroom (Agaricus bisporus). International Journal of Biological Macromolecules, 106, 218-226.

Ojeda, G. A., Sgroppo, S. C., Martín-Belloso, O., \& Soliva-Fortuny, R. (2019). Chitosan/ tripolyphosphate nanoaggregates enhance the antibrowning effect of ascorbic acid on mushroom slices. Postharvest Biology and Technology, 156, 110934.

Ojha, K. S., Tiwari, B. K., \& Donnell, C. P. O. (2018). Effect of ultrasound technology on food and nutritional quality. Advances in Food \& Nutrition Research, 84, 207-240. https://doi.org/10.1016/bs.afnr.2018.01.001

Oliveira, M., Abadias, M., Usall, J., Torres, R., Teixidó, N., \& Viñas, I. (2015). Application of modified atmosphere packaging as a safety approach to fresh-cut fruits and vegetables - a review. Trends in Food Science \& Technology, 46, 13-26. https://doi. org/10.1016/j.tifs.2015.07.017

Oludemi, T., Barros, L., Prieto, M. A., Heleno, S. A., Barreiro, M. F., \& Ferreira, I. C. F. R. (2018). Extraction of triterpenoids and phenolic compounds from Ganoderma lucidum : Optimization study using the response surface methodology. Food \& Function. https://doi.org/10.1039/C7FO01601H

Parniakov, O., Deng, Q., Patras, A., \& Rosello, E. (2016). Application of non-conventional extraction methods: Toward a sustainable and green production of valuable compounds from mushrooms. Food Engineering Reviews, 8(2), 214-234. https://doi. org/10.1007/s12393-015-9131-1

Pei, F., Yang, W., Ma, N., Fang, Y., Zhao, L., An, X., et al. (2016). Effect of the two drying approaches on the volatile profiles of button mushroom (Agaricus bisporus) by headspace GC e MS and electronic nose. Lebensmittel-Wissenschaft und -TechnologieFood Science and Technology, 72, 343-350. https://doi.org/10.1016/j. lwt.2016.05.004

Pinela, J., Prieto, M. A., Barros, L., Maria, A., Oliveira, M. B. P. P., Saraiva, J. A., et al. (2018). Cold extraction of phenolic compounds from watercress by high hydrostatic pressure: Process modelling and optimization. Separation and Purification Technology, 192, 501-512. https://doi.org/10.1016/j.seppur.2017.10.007. August 2017.

Piskov, S., Timchenko, L., Grimm, W. D., Rzhepakovsky, I., Avanesyan, S., Sizonenko, M., et al. (2020). Effects of various drying methods on some physico-chemical properties and the antioxidant profile and ACE inhibition activity of oyster mushrooms (Pleurotus ostreatus). Foods, 9(2). https://doi.org/10.3390/foods9020160 
Qi, L., Zhang, M., Mujumdar, A. S., Meng, X.-Y., \& Chen, H.-Z. (2014). Comparison of drying characteristics and quality of shiitake mushrooms (Lentinus edodes) using different drying methods. Drying Technology, 32(15), 1751-1761.

Rathore, H., Prasad, S., \& Sharma, S. (2017). Mushroom nutraceuticals for improved nutrition and better human health: A review. PharmaNutrition, 5(2), 35-46.

Reis, F. S., Martins, A., Vasconcelos, M. H., Morales, P., \& Ferreira, I. C. F. R. (2017). Functional foods based on extracts or compounds derived from mushrooms. Trends in Food Science \& Technology, 66, 48-62. https://doi.org/10.1016/j.tifs.2017.05.010

Roncero-Ramos, I., \& Delgado-Andrade, C. (2017). The beneficial role of edible mushrooms in human health. Current Opinion in Food Science, 14, 122-128. https:// doi.org/10.1016/j.cofs.2017.04.002

Salgado, P. R., Ortiz, C. M., Musso, Y. S., Di Giorgio, L., \& Mauri, A. N. (2015). Edible films and coatings containing bioactives. Current Opinion in Food Science, 5, 86-92.

Sande, D., de Oliveira, G. P., Moura, M. A. F.e., Martins, B. de A., Lima, M. T. N. S., \& Takahashi, J. A. (2019). Edible mushrooms as a ubiquitous source of essential fatty acids. Food Research International, 125, 108524. https://doi.org/10.1016/j. foodres.2019.108524. March.

Sapers, G. M., Miller, R. L., Choi, S.-W., \& Cooke, P. H. (1999). Structure and composition of mushrooms as affected by hydrogen peroxide wash. Journal of Food Science, 64(5), 889-892.

Shimizu, T., Kawai, J., Ouchi, K., Kikuchi, H., Osima, Y., \& Hidemi, R. (2016). Agarol, an ergosterol derivative from Agaricus blazei, induces caspase-independent apoptosis in human cancer cells. International Journal of Oncology, 48(4), 1670-1678. https://doi. org/10.3892/ijo.2016.3391

Shishir, M. R. I., Karim, N., Bao, T., Gowd, V., Ding, T., Sun, C., et al. (2019). Cold plasma pretreatment-A novel approach to improve the hot air drying characteristics, kinetic parameters, and nutritional attributes of shiitake mushroom. Drying Technology, 1-17. https://doi.org/10.1080/07373937.2019.1683860, 0(0).

Simon, R. R., Phillips, K. M., Horst, R. L., \& Munro, I. C. (2011). Vitamin D mushrooms: Comparison of the composition of button mushrooms (Agaricus bisporus) treated postharvest with UVB light or sunlight. Journal of Agricultural and Food Chemistry, 59 (16), 8724-8732.

Sławińska, A., Fornal, E., Radzki, W., Skrzypczak, K., Zalewska-Korona, M., MichalakMajewska, M., et al. (2016). Study on Vitamin D2 stability in dried mushrooms during drying and storage. Food Chemistry, 199, 203-209. https://doi.org/10.1016/ j.foodchem.2015.11.131

Taofiq, O., Corrêa, R. C. G., Barros, L., Prieto, M. A., Bracht, A., Peralta, R. M., et al. (2019). A comparative study between conventional and non-conventional extraction techniques for the recovery of ergosterol from Agaricus blazei Murrill. Food Research International, 125, 108541. https://doi.org/10.1016/j.foodres.2019.108541. May 2018.

Taofiq, O., Fernandes, Â., Barros, L., Barreiro, M. F., \& Ferreira, I. C. F. R. (2017). UVirradiated mushrooms as a source of vitamin D2: A review. Trends in Food Science \& Technology, 70, 82-94. https://doi.org/10.1016/j.tifs.2017.10.008. October.

Taofiq, O., Martins, A., Barreiro, M. F., \& Ferreira, I. C. F. R. (2016). Anti-inflammatory potential of mushroom extracts and isolated metabolites. Trends in Food Science \& Technology, 50, 193-210. https://doi.org/10.1016/j.tifs.2016.02.005

Tian, Y., Zhao, Y., Huang, J., Zeng, H., \& Zheng, B. (2016). Effects of different drying methods on the product quality and volatile compounds of whole shiitake mushrooms. Food Chemistry, 197, 714-722. https://doi.org/10.1016/j. foodchem.2015.11.029

Ucar, T. M., \& Karadag, A. (2019). The effects of vacuum and freeze-drying on the physicochemical properties and in vitro digestibility of phenolics in oyster mushroom (Pleurotus ostreatus). Journal of Food Measurement and Characterization, 13 (3), 2298-2309. https://doi.org/10.1007/s11694-019-00149-w
Valverde, M. E., Hernández-Pérez, T., \& Paredes-López, O. (2015). Edible mushrooms: Improving human health and promoting quality life. International Journal of Microbiology, 376-387, 2015.

Wani, B. A., Bodha, R. H., \& Wani, A. H. (2010). Nutritional and medicinal importance of mushrooms. Journal of Medicinal Plants Research, 4(24), 2598-2604.

Wu, Y., Hu, Q., Li, Z., Pei, F., Mugambi Mariga, A., \& Yang, W. (2019). Effect of nanocomposite-based packaging on microstructure and energy metabolism of Agaricus bisporus. Food Chemistry, 276, 790-796. https://doi.org/10.1016/j. foodchem.2018.10.088. June 2018.

Wu, S., Nie, Y., Zhao, J., Fan, B., Huang, X., Li, X., et al. (2018). The synergistic effects of low-concentration acidic electrolyzed water and ultrasound on the storage quality of fresh-sliced button mushrooms. Food and Bioprocess Technology, 11(2), 314-323.

Wu, F., Tang, J., Pie, F., Wang, S., Chen, G., Hu, Q., et al. (2015). The influence of four drying methods on nonvolatile taste components of White Hypsizygus marmoreus. European Food Research and Technology, 240(4), 823-830.

Wu, X. fei, Zhang, M., \& Bhandari, B. (2019). A novel infrared freeze drying (IRFD) technology to lower the energy consumption and keep the quality of Cordyceps militaris. Innovative Food Science \& Emerging Technologies, 54, 34-42. https://doi. org/10.1016/j.ifset.2019.03.003. March.

Wu, X. fei, Zhang, M., Bhandari, B., \& Li, Z. (2019). Effects of microwave assisted pulse fluidized bed freeze-drying (MPFFD) on quality attributes of Cordyceps militaris. Food Bioscience, 28, 7-14. https://doi.org/10.1016/j.fbio.2019.01.001. January.

Xu, L., Fang, X., Wu, W., Chen, H., Mu, H., \& Gao, H. (2019). Effects of high-temperature pre-drying on the quality of air-dried shiitake mushrooms (Lentinula edodes). Food Chemistry, 285, 406-413. https://doi.org/10.1016/j.foodchem.2019.01.179. February.

Yue, L., Cui, H., Li, C., Lin, Y., Sun, Y., Niu, Y., et al. (2012). A polysaccharide from Agaricus blazei attenuates tumor cell adhesion via inhibiting E-selectin expression. Carbohydrate Polymers, 88(4), 1326-1333. https://doi.org/10.1016/j. carbpol.2012.02.015

Yuk, H.-G., Yoo, M.-Y., Yoon, J.-W., Marshall, D. L., \& Oh, D.-H. (2007). Effect of combined ozone and organic acid treatment for control of Escherichia coli O157: H7 and Listeria monocytogenes on enoki mushroom. Food Control, 18(5), 548-553.

Zalewska, M., Marcinkowska-Lesiak, M., \& Onopiuk, A. (2018). Physicochemical properties of white button mushrooms (Agaricus bisporus) as affected by coating. Journal of Food Processing and Preservation, 42(2), Article e13419.

Zhang, Z., Liu, Z., Liu, C., Li, D., \& Jiang, N. (2016). Effects of ultrasound pretreatment on drying kinetics and quality parameters of button mushroom slices. Drying Technology, 34(15), 1791-1800. https://doi.org/10.1080/07373937.2015.1117486

Zhang, L., Liu, Z., Sun, Y., Wang, X., \& Li, L. (2020). Combined antioxidant and sensory effects of active chitosan/zein film containing $\alpha$-tocopherol on Agaricus bisporus. Food Packaging and Shelf Life, 24, 100470.

Zhang, S., Nie, S., Huang, D., Feng, Y., \& Xie, M. (2014). A novel polysaccharide from Ganoderma atrum exerts antitumor activity by activating mitochondria-mediated apoptotic pathway and boosting the immune system. Journal of Agricultural and Food Chemistry, 62(7), 1581-1589. https://doi.org/10.1021/jf4053012

Zhang, K., Pu, Y.-Y., \& Sun, D.-W. (2018). Recent advances in quality preservation of postharvest mushrooms (Agaricus bisporus): A review. Trends in Food Science \& Technology, 78, 72-82.

Zhao, Y., Yi, J., Bi, J., Chen, Q., \& Zhou, M. (2018). Improving of texture and rehydration properties by ultrasound pretreatment for infrared-dried shiitake mushroom slices. Drying Technology, 37(3), 352-362.

Zhu, D., Guo, R., Li, W., Song, J., \& Cheng, F. (2019). Improved postharvest preservation effects of Pholiota nameko mushroom by sodium Alginate-based edible composite coating. Food and Bioprocess Technology, 12(4), 587-598. https://doi.org/10.1007/ s11947-019-2235-5 